\title{
Development and Testing of Polar WRF. Part III: Arctic Land*
}

\author{
KEITH M. HiNES \\ Polar Meteorology Group, Byrd Polar Research Center, The Ohio State University, Columbus, Ohio \\ DAVID H. BROMWICH \\ Polar Meteorology Group, Byrd Polar Research Center, and Atmospheric Sciences Program, \\ Department of Geography, The Ohio State University, Columbus, Ohio \\ LE-SHENG BAI \\ Polar Meteorology Group, Byrd Polar Research Center, The Ohio State University, \\ Columbus, Ohio \\ MiCHAEL BARLAGE \\ National Center for Atmospheric Research, Boulder, Colorado \\ ANDREW G. SLATER \\ Cooperative Institute for Research in Environmental Sciences, University of Colorado, \\ Boulder, Colorado
}

(Manuscript received 2 October 2009, in final form 11 June 2010)

\begin{abstract}
A version of the state-of-the-art Weather Research and Forecasting model (WRF) has been developed for use in polar climates. The model known as "Polar WRF" is tested for land areas with a western Arctic grid that has $25-\mathrm{km}$ resolution. This work serves as preparation for the high-resolution Arctic System Reanalysis of the years 2000-10. The model is based upon WRF version 3.0.1.1, with improvements to the Noah land surface model and snow/ice treatment. Simulations consist of a series of 48 -h integrations initialized daily at 0000 UTC, with the initial $24 \mathrm{~h}$ taken as spinup for atmospheric hydrology and boundary layer processes. Soil temperature and moisture that have a much slower spinup than the atmosphere are cycled from 48-h output of earlier runs. Arctic conditions are simulated for a winter-to-summer seasonal cycle from 15 November 2006 to 1 August 2007. Simulation results are compared with a variety of observations from several Alaskan sites, with emphasis on the North Slope. Polar WRF simulation results show good agreement with most near-surface observations. Warm temperature biases are found for winter and summer. A sensitivity experiment with reduced soil heat conductivity, however, improves simulation of near-surface temperature, ground heat flux, and soil temperature during winter. There is a marked deficit in summer cloud cover over land with excessive incident shortwave radiation. The cloud deficit may result from anomalous vertical mixing of moisture by the turbulence parameterization. The new snow albedo parameterization for WRF 3.1.1 is successfully tested for snowmelt over the North Slope of Alaska.
\end{abstract}

* Byrd Polar Research Center Contribution Number 1395.

Corresponding author address: Keith M. Hines, Polar Meteorology Group, Byrd Polar Research Center, The Ohio State University, 1090 Carmack Road, Columbus, OH 43210-1002.

E-mail: hines.91@osu.edu

\section{Introduction}

Concerns about recent climate change in the Arctic have often highlighted the loss of summer sea ice (e.g., Stroeve et al. 2007). Yet, the Arctic land surfaces are also crucial for the regional climate sensitivity. A prominent example is the possible thawing of the permafrost layer, 
estimated to cover about $24 \%$ of the Northern Hemisphere (Zhang et al. 2008). Loss of permafrost could affect freshwater discharge into the Arctic Ocean (Serreze et al. 2002) and carbon introduction into the atmosphere (Zimov et al. 2006). Furthermore, studies are finding evidence for changes in Arctic flora, including increased shrub growth for some tundra surfaces and browning of others, increased vegetative shading of snow cover, lengthening growing seasons, increased burn coverage, and expansion of boreal forests, which currently cover about $17 \%$ of global land area, into adjacent tundra (Chapin et al. 2000, 2005; McGuire et al. 2003; Juday et al. 2005; Lloyd and Bunn 2007). Changes in Arctic vegetation do not necessarily represent a passive response to a climate change, rather active participation can occur through a number of feedbacks (e.g., Euskirchen et al. 2009). Within the atmosphere, summertime atmospheric temperatures over Alaska are found to be warming, with the largest contribution attributed to earlier onset of seasonal snowmelt (Stone et al. 2002; Chapin et al. 2005).

Findings of heightened climate variability and change encourage detailed studies of Arctic phenomena with advanced numerical models (e.g., Roberts et al. 2009). While some of these studies have been with global climate models (e.g., Lawrence and Slater 2005; Lawrence et al. 2008), regional climate models have also been employed for both higher horizontal resolution and special emphasis on the Arctic. For example, Tjernström et al. (2005) and Rinke et al. (2006) show results for several regional climate models during the Arctic Regional Climate Model Intercomparison Project (ARCMIP) that simulated the test period for the Surface Heat Budget of the Arctic Ocean (SHEBA; Uttal et al. 2002). That 1997/ 98 field program provided an unprecedented set of detailed measurements over the pack ice of the Arctic Ocean.

For emphasis on northern Alaska land, past regional climate modeling work included a series of studies with the Arctic Region Climate System Model (ARCSyM) model adapted by Lynch et al. (1995) from the secondgeneration regional climate model of Giorgi et al. (1993). For example, Lynch et al. (1998) model the role of land surface processes during the spring snowmelt. Other examples include evaluating the sensitivity to soil moisture and vegetation type (Lynch et al. 1999a), comparing the modeled surface energy balance to observations (Lynch et al. 1999b), and studying the Arctic frontal zone (Lynch et al. 2001). The last case included sensitivity tests that detailed the dependency of surface fluxes to land use type.

The present study conducts a regional model evaluation with emphasis on simulation results over Arctic land, especially the North Slope of Alaska (NSA). The next section details the numerical model. Section 3 describes the western Arctic domain and briefly lists the synoptic conditions for the study period. Observations used for comparison with model results are detailed in section 4 . Results of simulation from November 2006 to July 2007 are shown in section 5 , and sensitivity simulations are discussed in section 6. Finally, conclusions are stated in section 7.

\section{Polar WRF}

Simulations are conducted with a polar-optimized version of the Weather Research and Forecasting model (WRF; available online at http://www.wrf-model.org) (Skamarock et al. 2005, 2008), and the results are compared to Arctic land-based observations from Alaska. The model known as Polar WRF (available online at http:// polarmet.osu.edu/PolarMet/pwrf.html) was introduced by Hines and Bromwich (2008). Polar WRF is a currentgeneration regional climate model for the Arctic and Antarctic that replaces the earlier Polar MM5, which was based upon the fifth-generation Pennsylvania State University-National Center for Atmospheric Research (PSU-NCAR) Mesoscale Model (MM5; e.g., Bromwich et al. 2001). Testing of Polar WRF is organized into a set of simulations for the climate over three key surface categories, beginning with the simulations emphasizing large permanent ice sheets, especially with the Greenland/North Atlantic grid employed by Hines and Bromwich (2008). Testing for ice sheet domains is supplemented by real-time, high-resolution Antarctic numerical forecasts through the Antarctic Mesoscale Prediction System (AMPS; Bromwich et al. 2003; Powers et al. 2003) in support of operational and logistic needs of the United States Antarctic Program. Polar ocean/sea ice was selected as the second surface category, with the SHEBA study during 1997/98 providing an ideal test period. For this case, Bromwich et al. (2009) used a western Arctic grid and compared their model results to the detailed observations at the floating SHEBA ice camp. They found very good results for most atmospheric variables during the three test months of January, June, and August 1998, representing midwinter, early-summer, and late-summer conditions, respectively. As expected, Arctic clouds and the associated longwave and shortwave radiation were not as well simulated as the surface pressure, near-surface temperature, and near-surface wind fields.

For the third surface category, we now test Polar WRF for the climate over Arctic land. The testing and development of the model are key steps toward the Arctic System Reanalysis (ASR; available online at http://polarmet.osu. edu/PolarMet/ASR.html) (Bromwich et al. 2010) project that will assimilate available remote sensing and in situ data into a $10-\mathrm{km}$-resolution depiction of the coupled 
Arctic atmosphere-land-ocean system for the years 2000-10. Polar WRF will serve as the base model for the ASR in combination with three-dimensional variational data assimilation (3DVAR) of meteorological quantities (e.g., Barker et al. 2004; Lee 2005). In the WRF variational data assimilation (WRF-Var) system, observations are combined with WRF to achieve an optimal estimate of the atmospheric state through an iterative solution of a cost function (Skamarock et al. 2008). A prototype ASR simulation, including data assimilation, was run with 30$\mathrm{km}$ resolution on a large Arctic domain for June 2007September 2008 (Bromwich et al. 2010). In the present study, we present regional simulations over the west Arctic without data assimilation and concentrate on results at sites of scientific observing programs along the NSA.

Preparations for the ASR are also complemented by 60-km horizontal-resolution simulations with Polar WRF 3.1.1 for the year 2007 over the ASR domain (Wilson 2010). The $60-\mathrm{km}$ run was compared to standard meteorological observations for many sites across the Arctic. Wilson (2010) found small biases for the temperature near the surface and at upper levels. There was a deficit in annual Arctic precipitation, however, of $0.275 \mathrm{~m}$, with a maximum seasonal deficit of $0.097 \mathrm{~m}$ during summer.

The simulations presented here are based upon Polar WRF adapted from version 3.0.1.1 of the Advanced Research WRF (ARW-WRF), a modular, nonhydrostatic model designed for both research and operational applications (Skamarock et al. 2008). The time step is $120 \mathrm{~s}$. The simulations shown here have the same 28 terrainfollowing sigma layers between the earth's surface and the 10-hPa model top as in Hines and Bromwich (2008) and Bromwich et al. (2009). The top is set at a high level for better treatment of upward-propagating gravity waves generated by topography (e.g., Guo et al. 2003; Bromwich et al. 2005a). The highest vertical resolution is in the boundary layer, with the lowest 10 layers centered at approximately $14,42,75,118,171,238,325,433,561$, and $748 \mathrm{~m}$, respectively, above the surface.

A set of physical parameterization options is selected based upon the work of Hines and Bromwich (2008) and Bromwich et al. (2009). Subgrid-scale cumulus is parameterized with the Grell and Dévényi (2002) ensemble scheme, as the earlier Grell scheme gave good results for Polar MM5 simulations of summer climate near the Laurentide ice sheet (Bromwich et al. 2005b). Selected radiation schemes include the Rapid Radiative Transfer Model for longwave and the Goddard scheme for shortwave. For cloud physics, we use the Morrison et al. (2005) bulk microphysics scheme that is two-moment for cloud ice, cloud liquid, rain, snow, and graupel. The performance over the Arctic Ocean of the Morrison microphysics was found to be equal to or better than that of other microphysics schemes (Bromwich et al. 2009).

Lower atmospheric and surface physics include the use of the Mellor-Yamada-Janjić (MYJ) planetary boundary layer scheme, run in conjunction with the Eta surface layer scheme based on similarity theory (Janjić 2002). The land surface model (LSM) is the four-layer unified Noah 3.0 scheme (Ek et al. 2003; Skamarock et al. 2005; Chen et al. 2007; Slater et al. 2007), with the polar updates from Hines and Bromwich (2008). The four layers are centered at $0.05,0.25,0.7$, and $1.5 \mathrm{~m}$ deep in the soil. The sea ice layers, however, are all $0.75 \mathrm{~m}$ thick within a constant 3-m thickness of pack ice for this version of the model. Updates to the LSM include modifications to the surface energy balance that determines the skin temperature over permanent ice and sea ice. For permanent ice surfaces, the snow firn heat transfer, thermal conductivity, heat capacity, and density are modified within the Noah LSM to more closely match those of Polar MM5. The simulations include the fractional sea ice treatment of Bromwich et al. (2009) that provides for different surface temperature, surface roughness, sensible heat flux, and latent flux for the ice and open water portions of sea ice grid points. Sea ice fraction and open water sea surface temperature are updated every $6 \mathrm{~h}$.

Time and space variations of sea ice albedo were important considerations for Bromwich et al. (2009) with their Polar WRF simulations over Arctic pack ice. Bromwich et al.'s (2009) sea ice albedo treatment was inspired by Perovich et al.'s (2007) five-stage idealized model of the seasonal progression of Arctic sea ice albedo. The current study emphasizes results over land; nevertheless, we employ a similar approach here with the sea ice albedo set at 0.82 for winter and spring until the onset of snowmelt over sea ice. Sea ice albedo is then linearly decreased in time over 35 days until reaching the equilibrium value 0.5 , representing a mixture of bare ice and melt ponds. The onset of snowmelt over sea ice is taken as function of Julian day and latitude from a dataset provided by Mark Anderson of the University of Nebraska. During July, melt ponds are assumed to grow deeper and less reflective until they are treated as indistinguishable from open water at the end of the month. To represent this transition, sea ice albedo is set to increase linearly from the value 0.5 for a mixed surface to the value 0.65 , representative of ice, at the end of the month. Although this apparent increase in albedo may appear counterintuitive, the overall albedo in the pack ice domain should decrease because of an increased representation of open water fraction.

The albedo of snow over land also shows seasonal variation due to a variety of factors, especially melting and refreezing (e.g., Marshall and Oglesby 1994; Mölders 
et al. 2008). We use a simple formulation here to represent the seasonal change. Snow albedo is set at 0.80 prior to the onset of the spring snowmelt. The summer value is set at the reduced value 0.65 based upon the work of Warren (1982) and observations by Essery and Etchevers (2004). To set the snow albedo, the 2007 snowmelt onset is specified as a function of Julian day and latitude, analogous to that of sea ice albedo. Based upon the time series of surface temperature from the final analysis (FNL, see below) initial condition fields, a transition date is selected for each latitude when the zonal average surface temperature inside the domain warms during spring to near the freezing point. The selection is usually not difficult because of the strong seasonal warming trend. The transition time is set at 21 April for the southern portion of the domain. Snowmelt begins about 26 April in central Alaska near Fairbanks and reaches the latitude of Barrow by 26 May. The northernmost land areas within the domain in northwestern Canada show snowmelt by 6 June. Snow albedo decreases when the spring melt begins and the snow becomes wetter (Wendler and Eaton 1990). Therefore, a transition time of five days is then specified for each latitude during which the snow albedo decreases linearly from 0.8 to 0.65 . Although the snow albedo is modified by this procedure, the location and depth of snow in model initial conditions and the albedo of snow-free land are not changed.

\section{Arctic domain and 2007 conditions}

The Polar WRF simulations have the same western Arctic domain as Bromwich et al. (2009). The Lambert conformal grid shown in Fig. 1 has $141 \times 111$ grid points, extends $3500 \mathrm{~km}$ east to west and $2750 \mathrm{~km}$ north to south and is centered at $72^{\circ} \mathrm{N}, 153^{\circ} \mathrm{W}$. The domain is similar to the ARCMIP grid; however, the horizontal resolution is set at $25 \mathrm{~km}$. Table 1 describes the observing sites used for comparison with model results. Triangles in Fig. 1a show the location of the Atmospheric Radiation Measurement Program (ARM; Ackerman and Stokes 2003) NSA sites Barrow $\left(71.3233^{\circ} \mathrm{N}, 156.6158^{\circ} \mathrm{W}\right)$ and Atqasuk $\left(70.4720^{\circ} \mathrm{N}, 157.4081^{\circ} \mathrm{W}\right)$. Detailed atmospheric, radiative and cloud observations are available from these sites (Ellingson et al. 1999; Doran et al. 2006). Diamonds show locations of meteorological observations from several sites in the Kuparuk drainage basin in northeastern Alaska (Kane et al. 2003). These well-maintained sites are used for many studies, including the Land-AtmosphereIce Interactions (LAII) Flux Study (Kane and Reeburgh 1998). The large square shows the location of the Bonanza Creek Experimental Forest Long Term Ecological Research (LTER) sites in central Alaska (Hollingsworth
2005). The small squares represent the Kougarok $\left(65.4283^{\circ} \mathrm{N}, 164.6435^{\circ} \mathrm{W}\right)$ and Council sites $\left(64.8912^{\circ} \mathrm{N}\right.$, $163.6435^{\circ} \mathrm{W}$ ) on the Seward Peninsula in western Alaska. The Kuparuk and western Alaska stations are maintained by the Water and Environmental Research Center (WERC; available online at http://www.uaf.edu/water/ projects/) at the University of Alaska Fairbanks.

For the Polar WRF simulations of the Arctic domain, specified initial and boundary conditions for the atmospheric fields are taken from the National Centers for Environmental Prediction's (NCEP) Global Forecast System (GFS) FNL, available every $6 \mathrm{~h}$ at $1^{\circ}$ horizontal resolution (Global Climate and Weather Modeling Branch 2003). Sea surface temperature is also taken from the FNL. The fractional sea ice coverage for the ocean grid points is prescribed with daily sea ice concentrations from Advanced Microwave Scanning Radiometer for Earth Observing System (AMSR-E) observations at 25-km resolution (Cavalieri et al. 2004; Spreen et al. 2008).

For atmospheric quantities, spinup of Polar WRF is allowed to occur over a full day. The atmospheric output prior to hour 24 is discarded for each individual simulation (beginning at 0000 UTC daily), and instantaneous results starting at hour 24 are combined at 3-h intervals. Hines and Bromwich (2008) found that the 3-h interval captures well the diurnal cycle of incident radiation at Summit, Greenland.

Because of the slow spinup of soil variables (e.g., Lynch et al. 2001), however, a continuous simulation of soil temperature and moisture is performed through cycling the 48-h soil output into initial conditions at the appropriate valid time. Initial soil conditions for 15 November 2006 are taken from an offline 10-yr spinup of Noah using the Japanese 25-year Reanalysis Project (JRA-25; Onogi et al. 2007) as atmospheric forcing. The JRA-25 was believed to be the best contemporary global reanalysis available for this period (e.g., Bromwich et al. 2007). Noah deep soil boundary conditions are taken from an Arctic activelayer equilibrium temperature model.

Within the Arctic domain, $59.6 \%$ of the total area is taken up by either open ocean, sea ice, or permanent ice. For the rest of the domain shown in Fig. 1b, primary land use types assigned by the WRF preprocessing system include wooded tundra (light green, $51.1 \%$ ) and mixed tundra (yellow, $12.1 \%$ ) that is especially common near the Arctic coast. Shrubland (light blue, 10.9\%) is common over northwestern Canada and south of the Brooks Range in Alaska. Shades of green denote deciduous broadleaf forest $(7.1 \%)$, common in parts of western Canada, and mixed forest (6.7\%), common in central and western Alaska. Barren land (brown, 6.6\%) can be found in locations over extreme northern Canada. Several other land use types each occupy less than $3 \%$ of 

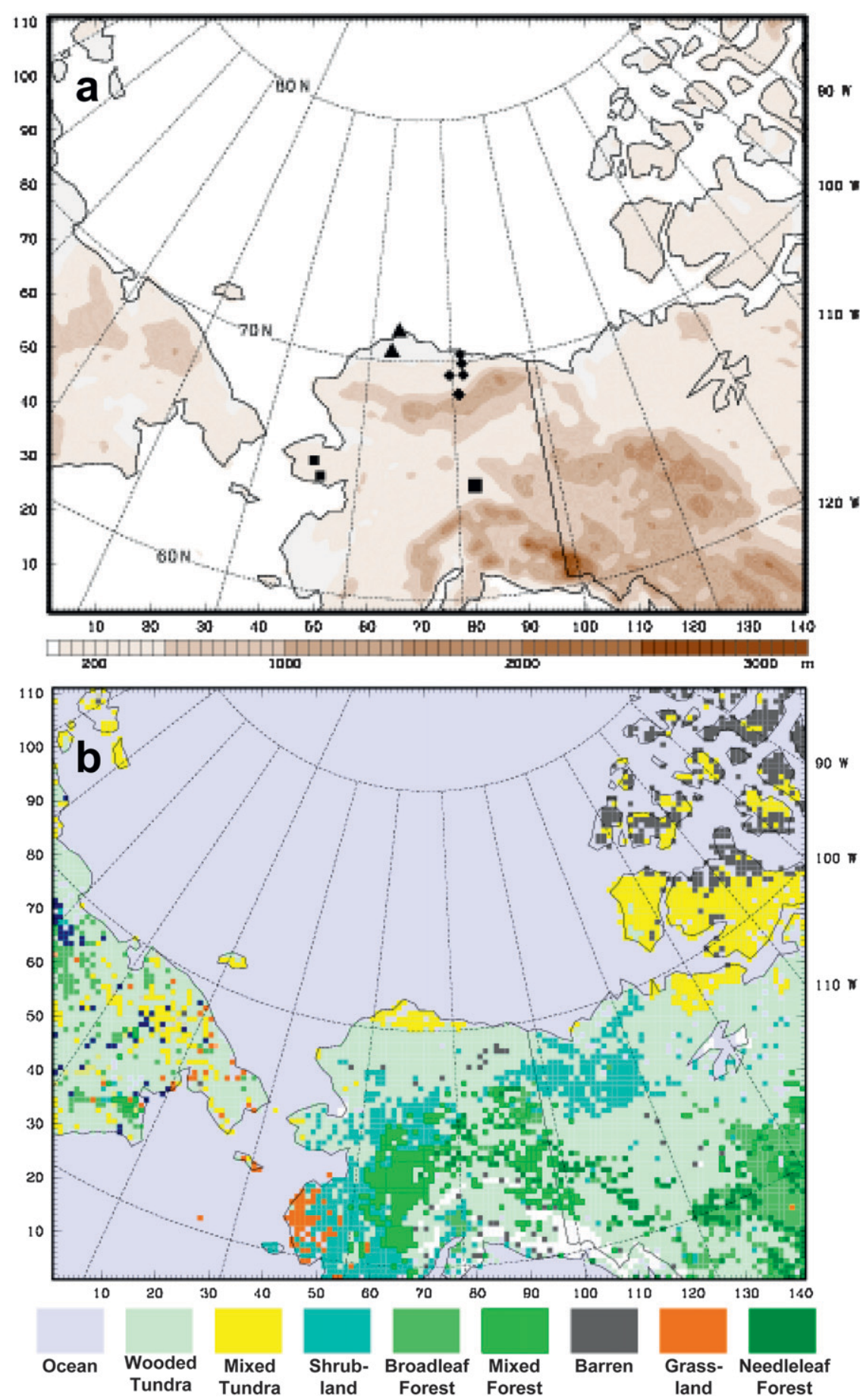

FIG. 1. Domain for the Polar WRF simulations showing (a) terrain height (color scale, $m$ ) and (b) land use type. Triangles show locations of observing sites Barrow and Atqasuk. Diamonds show Kuparuk drainage basin sites, and small squares show Kougarok and Council. Large square is Bonanza Creek. Label boxes in (b) show the nine most common land use types within the domain. 
TABLE 1. Observing sites for comparison with polar WRF results. An asterisk indicates the land use description from the University of Alaska Fairbanks WERC research projects' Web site.

\begin{tabular}{|c|c|c|c|c|c|}
\hline Location & Region & Elev (m MSL) & Land use & Lat $\left({ }^{\circ} \mathrm{N}\right)$ & Lon $\left({ }^{\circ} \mathrm{W}\right)$ \\
\hline Barrow & NSA & 7.6 & Wet sedge tundra & 71.3230 & 156.6090 \\
\hline Polar WRF land point & & 7.0 & Mixed tundra & 71.1668 & 156.8743 \\
\hline Polar WRF ocean point & & 1.4 & Ocean & 71.3936 & 156.9182 \\
\hline Atqasuk & NSA & 20 & Wet sedge tundra & 70.4718 & 157.4070 \\
\hline Polar WRF & & 15.4 & Mixed tundra & 70.4859 & 156.7845 \\
\hline Betty Pingo & NSA/Kuparuk & 11.6 & Marshy tundra* & 70.2795 & 148.8957 \\
\hline Polar WRF & & 13.5 & Mixed tundra & 70.2441 & 148.6194 \\
\hline Franklin Bluff & NSA/Kuparuk & 77.6 & Grass/moss tundra & 69.8922 & 148.7680 \\
\hline Polar WRF & & 92.0 & Wooded tundra & 69.7898 & 148.7112 \\
\hline Sagwon Hill & NSA/Kuparuk & 299 & Tussock* & 69.4243 & 148.6959 \\
\hline Polar WRF & & 277.1 & Wooded tundra & 69.3351 & 148.7992 \\
\hline West Kuparuk & NSA/Kuparuk & 158 & Tussock* & 69.4262 & 150.3404 \\
\hline Polar WRF & & 178.5 & Wooded tundra & 69.3609 & 150.0895 \\
\hline Upper Kuparuk & NSA/Kuparuk & 774 & Tussock & 68.6401 & 149.4065 \\
\hline Polar WRF & & 755 & Wooded tundra & 68.6663 & 149.5503 \\
\hline Fairbanks & Central Alaska & 132.3 & Forest/urban & 64.7317 & 147.8761 \\
\hline Polar WRF & & 190.3 & Wooded tundra & 64.7317 & 147.9120 \\
\hline Bonanza Creek LTER1 & Central Alaska & 355 & Forest (ridge) & 64.7417 & 148.3139 \\
\hline Bonanza Creek LTER2 & & 130 & Forest (floodplain) & 64.6989 & 148.2549 \\
\hline Polar WRF & & 216.8 & Mixed forest & 64.7492 & 148.4456 \\
\hline Kougarok & West Alaska/Seward & 110 & Tussock* & 65.4950 & 164.9100 \\
\hline Polar WRF & & 235.8 & Wooded tundra & 65.4950 & 164.9100 \\
\hline Council & West Alaska/Seward & 140 & Tussock/moss* & 64.8433 & 163.7053 \\
\hline Polar WRF & & 91.9 & Shrubland & 64.9018 & 163.5483 \\
\hline
\end{tabular}

the land area within the model domain. The Noah LSM does not allow for multiple land use types within a landbased grid point, or for mixed ocean and land grid points.

For the western Arctic, 2007 was a unique year. In particular, Arctic late-summer sea ice concentrations for 2007 were at record low amounts, with the Beaufort Sea especially affected (Kay et al. 2008; Stroeve et al. 2008). Early in the year, Fairbanks in central Alaska had abnormally low winter snowfall. In contrast, reports of the winter snow accumulation for the North Slope varied from near-normal amounts to exceptionally low values (e.g., Jones et al. 2009). Winter and spring were generally warmer than normal over Alaska, with exceptions of a record cold spell during March and close to normal January temperatures along the Arctic coast.

Summer temperatures were also warmer than normal. Fairbanks had about twice the normal precipitation during July, but Barrow only recorded $12 \mathrm{~mm}$ of precipitation during July. Correspondingly, exceptionally dry soil was measured near Umiat in the northern tundra region (Jones et al. 2009). Studies of the minimum summer sea ice event note unusually high pressure over the Beaufort Sea, reduced cloud cover over the Arctic Ocean north of Alaska, and increased solar insolation at the surface (Kay et al. 2008; Schweiger et al. 2008). The JuneAugust ceilometer-estimated cloud fraction at Barrow during 2007 was the smallest during 1998-2007 (Kay et al. 2008).

\section{Observational data}

The Barrow NSA site (available online at http:// newdesign.arm.gov/sites/nsa/barrow.stm) includes multiple instrument platforms, among those a 40-m tower with measurements at multiple levels. The other NSA site at Atqasuk is less extensively instrumented. It has a 5-m tower that samples basic meteorological fields at 2- and 5-m levels. At other sites, data used here are limited to temperature for quality control reasons. In central Alaska, near-surface temperature observations from the Bonanza Creek experimental forest are measured at 0.5 and $1.5 \mathrm{~m}$ above ground level. Large gaps in the observed record there are noted at LTER2 from 18 January to 22 March 2007 and from 23 May to 19 June. At LTER1, there is a gap from 8 to 21 May.

The Kuparuk sites measure temperature 1,3, and $10 \mathrm{~m}$ above ground level. Data were averaged from the lower two levels to estimate 2-m temperature for comparison with 2-m model results. A similar procedure is applied for Kougarok and Council in west Alaska.

For radiative studies, a suite of radiometers, including a precision spectral pyranometer, precision infrared radiometers, and a normal incident pyrheliometer, are 
installed and maintained at the NSA sites. The instruments are described by Doran et al. (2006). Each site has a multifilter rotating shadowband radiometer (MFRSR) that can take measurements of various shortwave irradiances, a microwave radiometer (MWR) that can measure liquid water path (LWP; the vertically integrated liquid water substance within a column) and precipitable water, and a Vaisala ceilometer. Barrow also has an atmospheric emitted radiance interferometer for longwave measurements and a Cimel sunphotometer that can measure shortwave narrowband radiance, and a total sky imager (TSI) can provide retrievals of fractional sky cover when the solar elevation is greater than $10^{\circ}$. At these sites, observations from the radiometers are combined with surface meteorological instruments using the Quality Control of Radiation Value Added Product (McFarlane et al.2009) to assess data quality and produce broadband radiative flux measurements. Derived from the measurements at Barrow, we obtained through Hans Verlinde of Pennsylvania State University the Climate Modeling Best Estimate (CMBE) product datastream of the ARM data specifically tailored for use in evaluating climate models. The CMBE fields include cloud fraction, surface radiation fluxes, total cloud cover, liquid water path, and precipitable water vapor. Radiative fluxes for Atqasuk are obtained from the ARM data server (available online at http://www.archive.arm.gov/). These include MFRSR downwelling shortwave flux, "best estimate" broadband downwelling shortwave flux (both diffuse and direct), and broadband downwelling longwave flux.

\section{Results}

\section{a. Pressure and temperature}

Walsh et al. (2008) find that the global climate models that perform best over the Arctic as a whole tend to perform best over Alaska and Greenland. Taking this as guidance for regional climate modeling studies, we now compare Polar WRF results to observations over Alaska, as Hines and Bromwich (2008) have already evaluated model performance over Greenland. Stafford et al. (2000) divide Alaska into four different climatic regions: Arctic, western, interior, and southern/southeastern. Stations from the first three regions are used for comparison with Polar WRF. Simulated values at the nearest landbased grid points are compared to the observed values at land stations. This avoids the complications associated with both interpolation from ocean to land and interpolation over different land use types. Differences in surface elevation between nearest model grid points and observations are never more than about $100 \mathrm{~m}$, and they are typically a few meters for coastal and lowland sites, including Barrow, Atqasuk, and Betty Pingo.

We begin with times series of meteorological fields at the NSA sites Barrow and Atqasuk, corresponding to the 15 November-1 August simulation. The nearest Polar WRF grid points used for the comparison are treated as mixed tundra by the Noah LSM. The following comparison concentrates on the period from December to July. Table 2 shows monthly statistical evaluations of model output, including surface pressure; temperature at $2 \mathrm{~m}, 40 \mathrm{~m}$, and $850 \mathrm{hPa}$; and wind speed, in comparison to in situ observations from selected Alaska locations. All of the correlations displayed are significant at the $99 \%$ confidence level, with a large majority significant at the $99.9 \%$ confidence level. At several sites observed temperature was available at 1 and $3 \mathrm{~m}$, consequently the value was averaged to $2 \mathrm{~m}$. Temperature observed at $1.5 \mathrm{~m}$ was used in place of $2-\mathrm{m}$ temperature for the central Alaska measurements from Bonanza Creek Experimental Forest sites LTER1 and LTER2. LTER1 is located along a ridge $355 \mathrm{~m}$ above mean sea level (MSL) less than $4 \mathrm{~km}$ northwest of the Tanana River. LTER2 is located at $130 \mathrm{~m}$ MSL along the river floodplain. For the 40-m temperature at Barrow, the model's second lowest level is very close to $40 \mathrm{~m}$ above ground level, so we compared the simulated temperature at this level directly to the tower observations. The observed $850-\mathrm{hPa}$ temperatures are from standard rawinsonde launches every $12 \mathrm{~h}$ at Barrow and Fairbanks.

Figure 2 displays the 3-h time series of surface pressure for the coastal NSA site Barrow from observations and from model results interpolated to the station height of 7.6 m. Figure 2a (Fig. 2b) shows December-March (April-July). Consistent with the results of Hines and Bromwich (2008) over Greenland and Bromwich et al. (2009) over the Arctic Ocean, the surface pressure time series is very well captured. Monthly correlations vary from a low of 0.95 for January to a high of 0.99 for March (Table 2). Correlations at the inland NSA site Atqasuk, located about $100 \mathrm{~km}$ southwest of Barrow, are similar. The bias in adjusted surface pressure is negative at Barrow, with a magnitude that averages $-1.2 \mathrm{hPa}$, and shows maxima in January and June and a minimum during April (Fig. 2c). The average bias for Atqasuk, $-0.3 \mathrm{hPa}$, has much smaller magnitude than that at Barrow. The dashed curve shows the bias of the nearest ocean grid point in comparison to the Barrow surface pressure observations. The average bias is zero for this ocean point, which is directly north of the Polar WRF land point. Moreover, the ocean point is located closer to the actual latitude and longitude of the Barrow observations (Table 1), so the apparent negative bias seen 
TABLE 2. Polar WRF monthly performance statistics. Polar WRF values are taken from nearest land point. Values for each station include bias (boldface), correlation (parentheses), and RSME (italics).

\begin{tabular}{|c|c|c|c|c|c|c|c|c|}
\hline Station & December & January & February & March & April & May & June & July \\
\hline \multicolumn{9}{|l|}{ Surface pressure $(\mathrm{hPa})$} \\
\hline \multirow[t]{2}{*}{ Barrow } & $\begin{array}{c}-\mathbf{1 . 2} \\
\left(0.98^{\mathrm{a}}\right)\end{array}$ & $\begin{array}{l}-\mathbf{1 . 6} \\
\left(0.95^{\mathrm{a}}\right)\end{array}$ & $\begin{array}{c}-\mathbf{1 . 1} \\
\left(0.98^{\mathrm{a}}\right)\end{array}$ & $\begin{array}{l}-\mathbf{1 . 0} \\
\left(0.99^{\mathrm{a}}\right)\end{array}$ & $\begin{array}{c}-\mathbf{0 . 6} \\
\left(0.98^{\mathrm{a}}\right)\end{array}$ & $\begin{array}{c}-\mathbf{1 . 4} \\
\left(0.98^{\mathrm{a}}\right)\end{array}$ & $\begin{array}{l}-\mathbf{1 . 6} \\
\left(0.98^{\mathrm{a}}\right)\end{array}$ & $\begin{array}{c}-\mathbf{1 . 2} \\
\left(0.97^{\mathrm{a}}\right)\end{array}$ \\
\hline & 2.4 & 3.2 & 2.1 & 2.2 & 1.9 & 1.8 & 2.1 & 1.5 \\
\hline \multirow[t]{3}{*}{ Atqasuk } & -0.5 & -0.6 & 0.0 & -0.2 & 0.3 & -0.2 & -0.6 & -0.2 \\
\hline & $\left(0.98^{\mathrm{a}}\right)$ & $\left(0.96^{\mathrm{a}}\right)$ & $\left(0.97^{\mathrm{a}}\right)$ & $\left(0.99^{\mathrm{a}}\right)$ & $\left(0.99^{\mathrm{a}}\right)$ & $\left(0.98^{\mathrm{a}}\right)$ & $\left(0.98^{\mathrm{a}}\right)$ & $\left(0.97^{\mathrm{a}}\right)$ \\
\hline & 2.0 & 2.5 & 1.9 & 1.8 & 1.5 & 1.0 & 1.5 & 0.9 \\
\hline \multicolumn{9}{|l|}{ 2-m temperature $(\mathrm{K})$} \\
\hline \multirow[t]{3}{*}{ Barrow } & -3.3 & -0.8 & 0.2 & 1.8 & 1.7 & 1.4 & 4.7 & 2.7 \\
\hline & $\left(0.91^{\mathrm{a}}\right)$ & $\left(0.67^{\mathrm{a}}\right)$ & $\left(0.87^{\mathrm{a}}\right)$ & $\left(0.84^{\mathrm{a}}\right)$ & $\left(0.86^{\mathrm{a}}\right)$ & $\left(0.88^{\mathrm{a}}\right)$ & $\left(0.64^{\mathrm{a}}\right)$ & $\left(0.62^{\mathrm{a}}\right)$ \\
\hline & 4.8 & 3.9 & 3.9 & 4.4 & 3.0 & 2.6 & 6.0 & 5.0 \\
\hline \multirow[t]{3}{*}{ Atqasuk } & -2.0 & 1.1 & 1.8 & 3.1 & 3.4 & 0.9 & 2.5 & -0.4 \\
\hline & $\left(0.89^{\mathrm{a}}\right)$ & $\left(0.80^{\mathrm{a}}\right)$ & $\left(0.91^{\mathrm{a}}\right)$ & $\left(0.87^{\mathrm{a}}\right)$ & $\left(0.88^{\mathrm{a}}\right)$ & $\left(0.93^{\mathrm{a}}\right)$ & $\left(0.87^{\mathrm{a}}\right)$ & $\left(0.81^{\mathrm{a}}\right)$ \\
\hline & 4.5 & 3.9 & 4.3 & 5.0 & 4.3 & 2.0 & 3.9 & 3.5 \\
\hline \multirow[t]{3}{*}{ Betty Pingo ${ }^{b}$} & -0.2 & 2.7 & 3.0 & 4.2 & 3.7 & 1.9 & 1.4 & -2.2 \\
\hline & $\left(0.78^{\mathrm{a}}\right)$ & $\left(0.74^{\mathrm{a}}\right)$ & $\left(0.88^{\mathrm{a}}\right)$ & $\left(0.86^{\mathrm{a}}\right)$ & $\left(0.84^{\mathrm{a}}\right)$ & $\left(0.91^{\mathrm{a}}\right)$ & $\left(0.75^{\mathrm{a}}\right)$ & $\left(0.77^{\mathrm{a}}\right)$ \\
\hline & 5.2 & 5.5 & 5.2 & 5.7 & 4.7 & 2.8 & 3.2 & 3.6 \\
\hline \multirow[t]{3}{*}{ Sagwon Hills ${ }^{\mathrm{b}}$} & 0.9 & 2.9 & 0.9 & 2.4 & 4.7 & 5.2 & 5.4 & 2.9 \\
\hline & $\left(0.80^{\mathrm{a}}\right)$ & $\left(0.84^{\mathrm{a}}\right)$ & $\left(0.94^{\mathrm{a}}\right)$ & $\left(0.94^{\mathrm{a}}\right)$ & $\left(0.80^{\mathrm{a}}\right)$ & $\left(0.89^{\mathrm{a}}\right)$ & $\left(0.80^{\mathrm{a}}\right)$ & $\left(0.88^{\mathrm{a}}\right)$ \\
\hline & 4.5 & 5.6 & 4.4 & 3.7 & 5.9 & 6.1 & 6.7 & 4.2 \\
\hline \multirow[t]{3}{*}{ West Kuparuk $^{\mathrm{b}}$} & 2.4 & 5.1 & 5.4 & 5.3 & 6.4 & 3.8 & 3.6 & 3.1 \\
\hline & $\left(0.78^{\mathrm{a}}\right)$ & $\left(0.80^{\mathrm{a}}\right)$ & $\left(0.92^{\mathrm{a}}\right)$ & $\left(0.92^{\mathrm{a}}\right)$ & $\left(0.83^{\mathrm{a}}\right)$ & $\left(0.88^{\mathrm{a}}\right)$ & $\left(0.79^{\mathrm{a}}\right)$ & $\left(0.91^{\mathrm{a}}\right)$ \\
\hline & 5.8 & 7.5 & 6.9 & 6.2 & 7.1 & 4.6 & 5.5 & 4.0 \\
\hline \multirow[t]{3}{*}{ Upper Kuparuk $^{\mathrm{b}}$} & 6.3 & 4.1 & 3.4 & 3.6 & 4.0 & 1.7 & 1.8 & 2.6 \\
\hline & $\left(0.63^{c}\right)$ & $\left(0.96^{\mathrm{a}}\right)$ & $\left(0.96^{\mathrm{a}}\right)$ & $\left(0.91^{\mathrm{a}}\right)$ & $\left(0.80^{\mathrm{a}}\right)$ & $\left(0.90^{\mathrm{a}}\right)$ & $\left(0.88^{\mathrm{a}}\right)$ & $\left(0.89^{\mathrm{a}}\right)$ \\
\hline & 8.6 & 5.1 & 4.8 & 4.7 & 6.1 & 3.7 & 3.2 & 3.6 \\
\hline \multirow[t]{3}{*}{ Bonanza Creek LTER $1^{\mathrm{d}}$} & 4.0 & 3.9 & 0.2 & -1.9 & -3.8 & -0.5 & 1.1 & 0.9 \\
\hline & $\left(0.92^{\mathrm{a}}\right)$ & $\left(0.93^{\mathrm{a}}\right)$ & $\left(0.96^{\mathrm{a}}\right)$ & $\left(0.88^{\mathrm{a}}\right)$ & $\left(0.85^{\mathrm{a}}\right)$ & $\left(0.84^{\mathrm{a}}\right)$ & $\left(0.89^{\mathrm{a}}\right)$ & $\left(0.87^{\mathrm{a}}\right)$ \\
\hline & 4.9 & 5.1 & 2.4 & 4.2 & 4.6 & 3.3 & 2.5 & 2.4 \\
\hline \multirow[t]{3}{*}{ Bonanza Creek LTER2 ${ }^{\mathrm{d}}$} & 9.0 & 7.7 & - & 0.4 & -1.9 & $\mathbf{0 . 0}$ & 0.9 & 1.0 \\
\hline & $\left(0.77^{\mathrm{a}}\right)$ & $\left(0.84^{\mathrm{a}}\right)$ & - & $\left(0.71^{\mathrm{a}}\right)$ & $\left(0.79^{\mathrm{a}}\right)$ & $\left(0.85^{\mathrm{a}}\right)$ & $\left(0.93^{\mathrm{a}}\right)$ & $\left(0.88^{\mathrm{a}}\right)$ \\
\hline & 10.0 & 9.1 & - & 6.6 & 4.8 & 3.4 & 2.3 & 2.6 \\
\hline \multirow[t]{3}{*}{ Kougarok $^{\mathrm{b}}$} & -1.1 & 0.1 & 0.3 & 2.3 & 2.1 & 1.3 & 1.4 & 1.4 \\
\hline & $\left(0.78^{\mathrm{a}}\right)$ & $\left(0.94^{\mathrm{a}}\right)$ & $\left(0.90^{\mathrm{a}}\right)$ & $\left(0.85^{\mathrm{a}}\right)$ & $\left(0.83^{\mathrm{a}}\right)$ & $\left(0.95^{\mathrm{a}}\right)$ & $\left(0.87^{\mathrm{a}}\right)$ & $\left(0.90^{\mathrm{a}}\right)$ \\
\hline & 4.8 & 4.0 & 4.4 & 4.4 & 3.4 & 2.5 & 2.6 & 2.7 \\
\hline \multirow[t]{3}{*}{ Council $^{\mathrm{b}}$} & -1.1 & -0.1 & -1.3 & 0.0 & 1.1 & 1.7 & 2.1 & 2.2 \\
\hline & $\left(0.92^{\mathrm{a}}\right)$ & $\left(0.95^{\mathrm{a}}\right)$ & $\left(0.94^{\mathrm{a}}\right)$ & $\left(0.92^{\mathrm{a}}\right)$ & $\left(0.80^{\mathrm{a}}\right)$ & $\left(0.96^{\mathrm{a}}\right)$ & $\left(0.88^{\mathrm{a}}\right)$ & $\left(0.89^{\mathrm{a}}\right)$ \\
\hline & 2.9 & 3.2 & 3.3 & 2.2 & 3.1 & 2.6 & 2.9 & 3.2 \\
\hline \multicolumn{9}{|l|}{ 40-m temperature $(\mathrm{K})$} \\
\hline \multirow[t]{3}{*}{ Barrow } & -4.4 & -1.9 & -1.4 & 0.1 & 1.0 & 0.9 & 3.8 & 1.9 \\
\hline & $\left(0.94^{\mathrm{a}}\right)$ & $\left(0.63^{\mathrm{a}}\right)$ & $\left(0.90^{\mathrm{a}}\right)$ & $\left(0.88^{\mathrm{a}}\right)$ & $\left(0.85^{\mathrm{a}}\right)$ & $\left(0.92^{\mathrm{a}}\right)$ & $\left(0.61^{\mathrm{a}}\right)$ & $\left(0.59^{\mathrm{a}}\right)$ \\
\hline & 5.0 & 4.0 & 3.7 & 3.3 & 2.7 & 1.9 & 5.2 & 4.5 \\
\hline \multicolumn{9}{|l|}{ 850-hPa temperature $(\mathrm{K})$} \\
\hline Barrow & - & 1.4 & 0.6 & 0.2 & 0.5 & 0.4 & 0.6 & 0.5 \\
\hline & - & $\left(0.89^{\mathrm{a}}\right)$ & $\left(0.98^{\mathrm{a}}\right)$ & $\left(0.95^{\mathrm{a}}\right)$ & $\left(0.90^{\mathrm{a}}\right)$ & $\left(0.98^{\mathrm{a}}\right)$ & $\left(0.96^{\mathrm{a}}\right)$ & $\left(0.75^{\mathrm{a}}\right)$ \\
\hline & - & 2.8 & 1.9 & 1.6 & 2.0 & 1.4 & 1.4 & 1.7 \\
\hline Fairbanks & - & 0.6 & 0.2 & 1.0 & -1.6 & -0.9 & -0.2 & 0.4 \\
\hline & - & $\left(0.95^{\mathrm{a}}\right)$ & $\left(0.97^{\mathrm{a}}\right)$ & $\left(0.92^{\mathrm{a}}\right)$ & $\left(0.88^{\mathrm{a}}\right)$ & $\left(0.92^{\mathrm{a}}\right)$ & $\left(0.91^{\mathrm{a}}\right)$ & $\left(0.76^{\mathrm{a}}\right)$ \\
\hline & - & 2.7 & 2.5 & 2.6 & 2.3 & 2.0 & 1.3 & 1.6 \\
\hline Wind speed $\left(\mathrm{m} \mathrm{s}^{-1}\right)$ & & & & & & & & \\
\hline 10-m Barrow & -0.9 & -0.4 & -1.2 & -0.3 & $-\mathbf{1 . 0}$ & -0.4 & 0.3 & -0.3 \\
\hline & $\left(0.75^{\mathrm{a}}\right)$ & $\left(0.89^{\mathrm{a}}\right)$ & $\left(0.72^{\mathrm{a}}\right)$ & $\left(0.73^{\mathrm{a}}\right)$ & $\left(0.69^{\mathrm{a}}\right)$ & $\left(0.70^{\mathrm{a}}\right)$ & $\left(0.64^{\mathrm{a}}\right)$ & $\left(0.67^{\mathrm{a}}\right)$ \\
\hline & 2.0 & 1.5 & 2.4 & 1.7 & 2.2 & 1.5 & 1.8 & 1.4 \\
\hline 5-/10-m Atqasuk & -1.0 & -0.9 & -0.7 & -1.0 & -0.8 & -1.5 & -0.1 & 0.3 \\
\hline & $\left(0.64^{\mathrm{a}}\right)$ & $\left(0.84^{\mathrm{a}}\right)$ & $\left(0.71^{\mathrm{a}}\right)$ & $\left(0.83^{\mathrm{a}}\right)$ & $\left(0.58^{\mathrm{a}}\right)$ & $\left(0.58^{\mathrm{a}}\right)$ & $\left(0.69^{\mathrm{a}}\right)$ & $\left(0.67^{\mathrm{a}}\right)$ \\
\hline & 2.4 & 2.2 & 2.2 & 2.0 & 2.4 & 2.4 & 1.8 & 1.6 \\
\hline
\end{tabular}

${ }^{\text {a }}$ Statistically significant at the $99.9 \%$ level.

${ }^{\mathrm{b}}$ Observations at these Kuparuk River area and Seward Peninsula sites are interpolated to $2 \mathrm{~m}$ by simple average of values at 1 and $3 \mathrm{~m}$ above ground level.

c Statistically significant at the $99 \%$ level.

${ }^{\mathrm{d}}$ Observations at $1.5 \mathrm{~m}$ are used. 

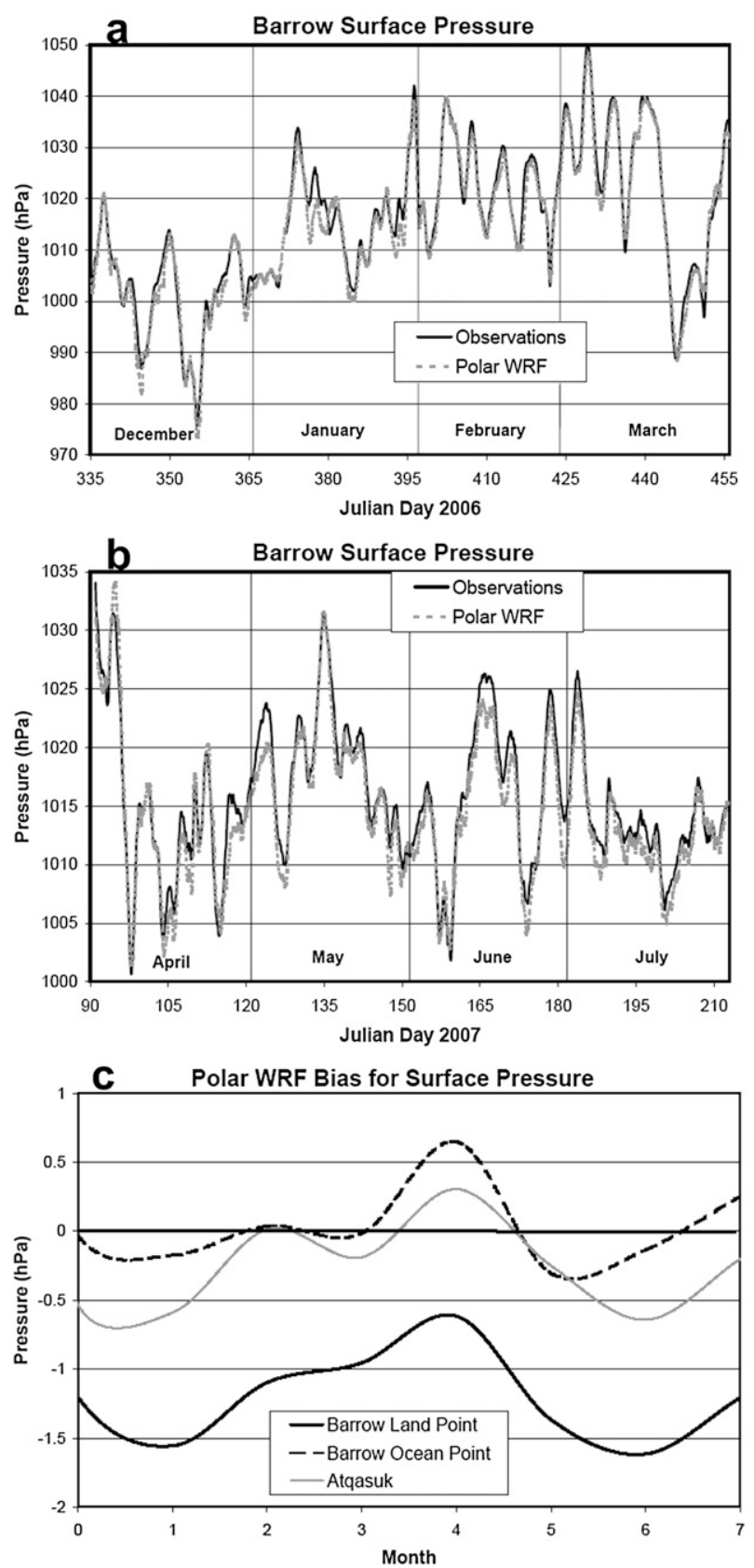

FIG. 2. Surface pressure $(\mathrm{hPa})$ from observations at Barrow and adjusted surface pressure from the nearest Polar WRF land grid point for (a) time series from December 2006 to March 2007 and (b) April-July 2007. (c) The monthly bias at Barrow and Atqasuk.

in Fig. $2 \mathrm{c}$ is probably primarily a result of the grid representation of the northern Alaska coastline. At the NSA sites, the overall small model error in surface pressure representation reflects the model successfully capturing the synoptic variability.

Figure 3 shows time series of 2-m temperature. No temperature corrections were applied for surface height differences between model and observations since the height differences were small. Two panels are shown for Barrow, while December-March is shown for Council, and April-July is shown for Atqasuk. At Barrow, the simulated and observed temperature display overall good agreement for the synoptic variability and seasonal change from December until late May. The bias at Barrow is $-3.3 \mathrm{~K}$ during December. The monthly magnitude, however, is less than $2 \mathrm{~K}$ from January to May (Table 2). The snow cover melts by early June, leading to a regime change. During the summer months of June and July, the simulated maximum daily temperature frequently exceeds the observed value by about $10 \mathrm{~K}$ at Barrow (Fig. 3b). The overall bias there is $4.7 \mathrm{~K}$ for June and $2.7 \mathrm{~K}$ for July. The error can be explained by the strong coastal influence on the Barrow observations (e.g., Doran et al. 2002; Walsh et al. 2009). Horizontal advection modulates the observed temperature at Barrow. The proximity of the observations to the ocean, however, will not be fully represented in the simulation by the $25 \mathrm{~km} \times 25 \mathrm{~km}$ land grid box. By comparison, several grid points to the south the bias is much smaller, $2.5 \mathrm{~K}$ for June and $-0.4 \mathrm{~K}$ for July at Atqasuk, which has a more continental climate (McFarlane et al. 2009). Similarly, the root-mean-square error (RMSE) peaks at Barrow in summer, but at Atqasuk the RMSE tends to be slightly less during June and July than during the winter months. The amplitude of the diurnal temperature cycle is much better captured at the inland NSA site, although the simulated magnitude is still about $3 \mathrm{~K}$ larger than that observed (see Fig. 4a). The coastal influence on summer temperature also affects the Kuparuk River basin in northeastern Alaska. Observed diurnal cycles of summer temperature (not shown) increase dramatically inland, proceeding from West Dock along the coast to Betty Pingo, a few kilometers inland, to Sagwon Hills and West Kuparuk, each about $100 \mathrm{~km}$ inland.

During the months with snow cover, the correlation of simulated $2-\mathrm{m}$ temperature to the observed value is generally high, 0.84 or larger, at Barrow. Similar correlations are found for 2-m dewpoint temperature (not shown) and 40-m temperature (Table 2). The exception is January, when the correlation is just 0.67 at Barrow for 2-m temperature.

The smaller correlation at Barrow probably results from the synoptic conditions during January 2007. That was a challenging month for the simulation, with temperature swings associated with mesoscale phenomena that affected northern Alaska. The highest monthly RMSE for surface pressure (3.2 for Barrow and $2.5 \mathrm{hPa}$ for Atqasuk) is during January. In particular, during 9-13 January a strong low approached Alaska from the west and, correspondingly, seasonally warm air was advected northward over 

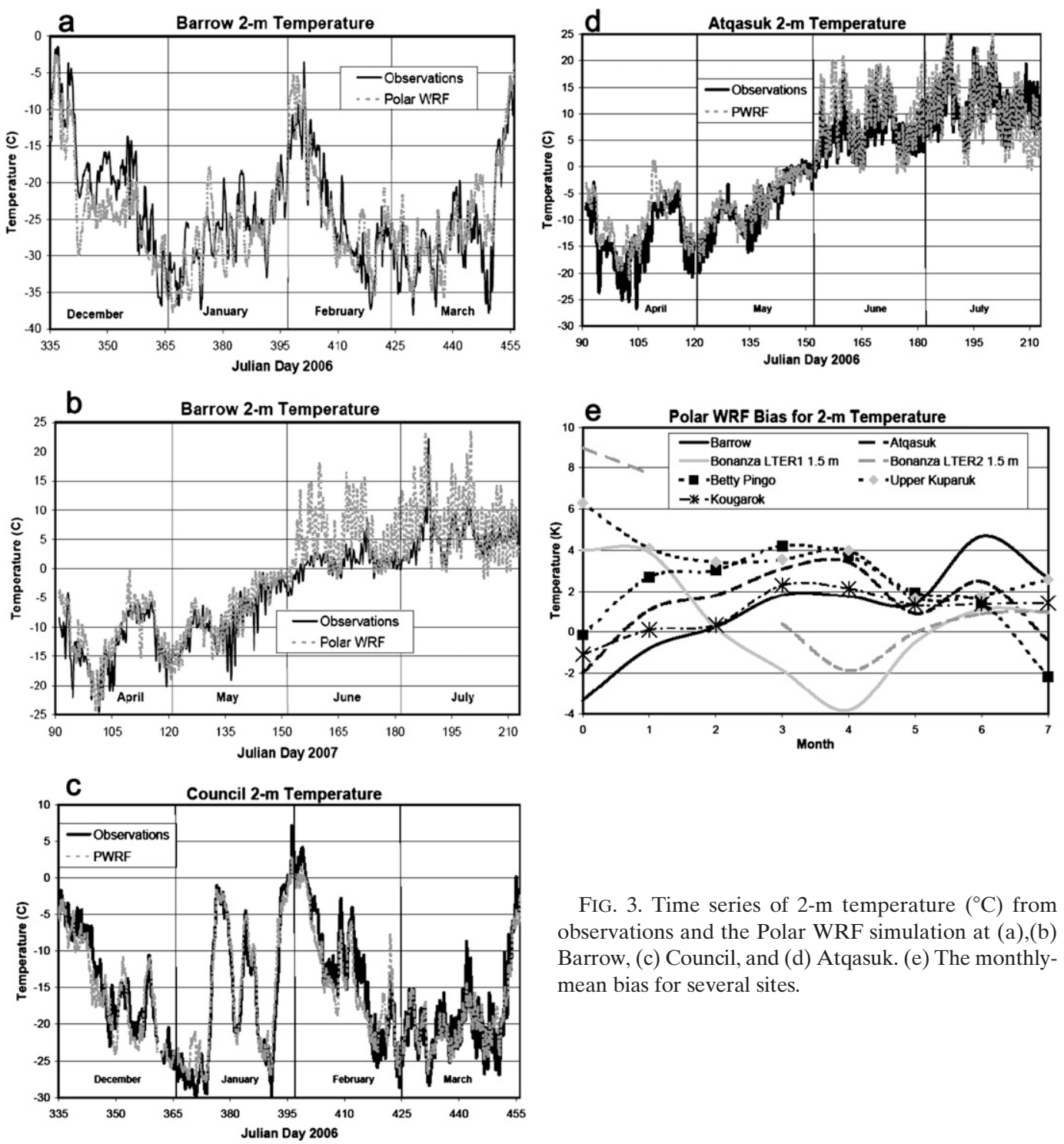

Alaska. Warming exceeded $20 \mathrm{~K}$ for some lower tropospheric regions, especially those in western Alaska, demonstrated by the dramatic midmonth temperature changes at Council on the Seward Peninsula (Fig. 3c). Conversely, a high pressure center developed over the western Beaufort Sea by 12 January and advected frigid air southward toward Alaska. The resulting confluence generated strong baroclinity over Alaska. Furthermore, mesoscale cold-air pockets drifted north of the Brooks Range during the middle of January. The difficulty in capturing these features can be seen in the pressure and temperature time series displayed in Figs. 2a and 3a, respectively, for Barrow. On the other hand, the correlation for 2-m temperature was high, 0.95, at Council for this month (Table 2).

During summer when the diurnal cycle of radiative forcing is large at the surface, the correlation at Barrow

for 2-m temperature falls below 0.65 for June and July. Correlations are generally higher at Atqasuk, above 0.85 for most months with snow cover, although 0.80 for January, and above 0.80 during the summer months of June and July. The summertime difference between Barrow and Atqasuk, including warmer temperature inland at the latter site, is readily apparent from Fig. 3. The simulated diurnal temperature cycle is much larger than that observed at Barrow (Fig. 3b). The difference is so large that the correlation is much reduced, and the RMSE is dominated by the diurnal contribution. At Atqasuk, however, the observed diurnal cycle is large and roughly corresponds to the simulated magnitude.

The ability of Polar WRF to capture the summertime diurnal cycle during July is examined with Fig. 4. At Atqasuk, the model's minimum daily temperature is 


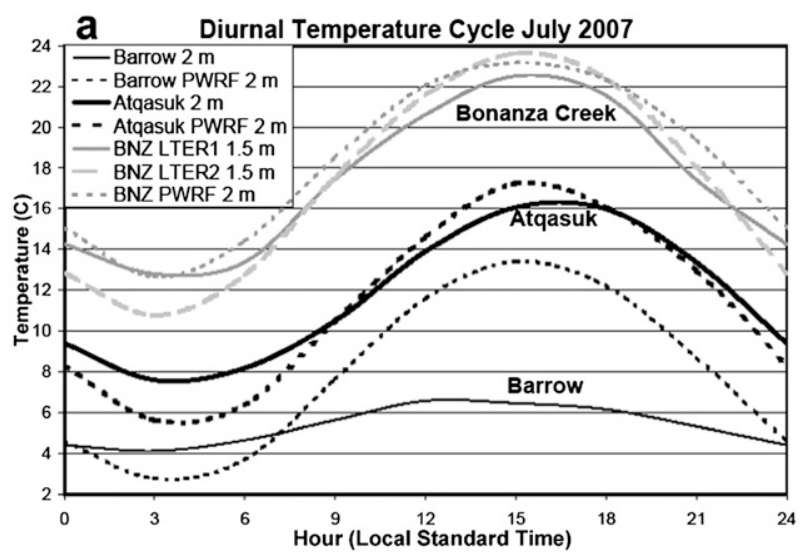

b Duirnal Temperature Cycle July 2007

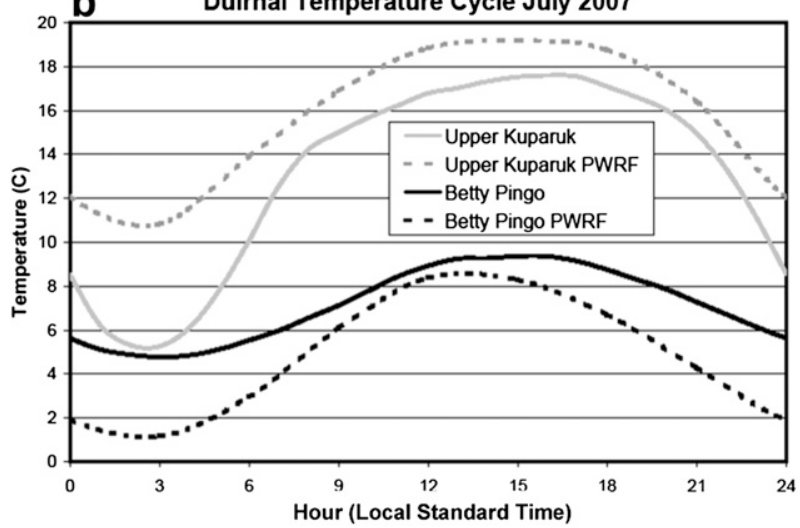

FIG. 4. Average diurnal cycle of July temperature $\left({ }^{\circ} \mathrm{C}\right)$ for $(\mathrm{a})$ Barrow, Atqasuk, and Bonanza Creek and (b) Betty Pingo and Upper Kuparuk for the observations (solid) and the simulation (dashed).

about $2 \mathrm{~K}$ colder than that observed, while the maximum shows a warm bias of about $1 \mathrm{~K}$ (Fig. 4a). The larger diurnal cycle in the simulation may reflect a dryer land surface (Table 1). In central Alaska, there is a net warm bias of about $1 \mathrm{~K}$ during July in comparison to LTER1 and LTER2 observations (Table 2). The floodplain site (LTER2) has a slightly larger observed diurnal cycle than the ridge site (LTER1). Polar WRF's daily minimum and maximum are both within the observed range displayed by LTER1 and LTER2.

On the other hand, the model displays a noticeable warm bias, both the winter and summer, for most of the Kuparuk Basin sites (Table 2). Subgrid-scale topographic influences in this basin may influence the observations at individual locations. A warm bias, however, is found for all months at all the inland sites. The bias, therefore, appears to be systematic. The monthly bias for Upper Kuparuk and Betty Pingo is shown in Fig. 3e. The 2-m temperature bias is usually larger than $2 \mathrm{~K}$ within the basin, with a maximum value of $6.4 \mathrm{~K}$ during April at West Kuparuk. For the three inland sites of Sagwon Hills, West Kuparuk, and Upper Kuparuk, the bias averages 3.5 K for December, January, and February and $3.2 \mathrm{~K}$ for June and July. Figure $4 \mathrm{~b}$ shows that the warm bias is present for all hours of the day at Upper Kuparuk during July. Maximum hourly bias exceeds $5 \mathrm{~K}$ at the time of minimum temperature. A warm bias at all hours is also found for the Julymean fields at Sagwon Hills and West Kuparuk; however, the hour of maximum bias varies (not shown). There is a large difference in the diurnal cycle, however, between Betty Pingo and Upper Kuparuk. The sites are about $200 \mathrm{~km}$ apart within the drainage basin. The observed hourly temperature stays below $10^{\circ} \mathrm{C}$ at the northern site, while afternoon temperature reaches $18^{\circ} \mathrm{C}$ at the southern site. The observed diurnal cycle at West Dock (not shown), which is near to Betty Pingo and closer to the Arctic Ocean, is less than that at Betty Pingo. The model moderately overestimates the amplitude of the diurnal cycle there. In contrast, the temperature biases are smaller for Kougarok and Council in western Alaska (Table 2; Fig. 3e).

To help diagnose the simulation of the summer nearsurface temperature, it is unfortunate that no observed estimate of sensible and latent heat fluxes is available for 2007. Climatological mean values for the summer, however, are available from Doran et al. (2006) for Barrow and Atqasuk from 1999 to 2001. Observed daily mean sensible heat flux and latent heat flux are typically about 30 (20) and $15(25) \mathrm{W} \mathrm{m}^{-2}$, respectively, at Barrow (Atqasuk). In contrast, the modeled values are 148.7 (136.1) and 17.2 (25.6) $\mathrm{W} \mathrm{m}^{-2}$ for July 2007. Thus, the daily mean latent heat flux simulated by Polar WRF appears similar to the previous observational estimates, but the sensible heat flux and therefore the Bowen ratio is much larger in the simulation. Harazono et al. (1998) show that the daily summertime surface energy balance for the North Slope is highly dependent on surface characteristics. The Polar WRF heat fluxes appear characteristic of dry tussock tundra for which radiation and sensible heat flux are the dominant thermodynamic processes (Harazono et al. 1998). In contrast, radiation, heat transfer with liquid water, and latent heat flux dominate for observed wet sedge tundra (Table 1). Doran et al. (2006) note that about $25 \%$ of the tundra surface is typically covered by lakes and melt ponds, so the Polar WRF simulation may not be representing the contribution of wet tundra to the net surface energy balance within the area.

Summer 2007, however, appears to be relatively dry on the North Slope according to soil moisture measurements at Umiat (Jones et al. 2009). Furthermore, satellite-derived summer cloud cover was below normal over the nearby Beaufort Sea, and observed incident solar radiation was $26 \mathrm{~W} \mathrm{~m}^{-2}$ greater than a 10 -yr mean value at Barrow (e.g., Kay et al. 2008). Given relatively dry conditions with 

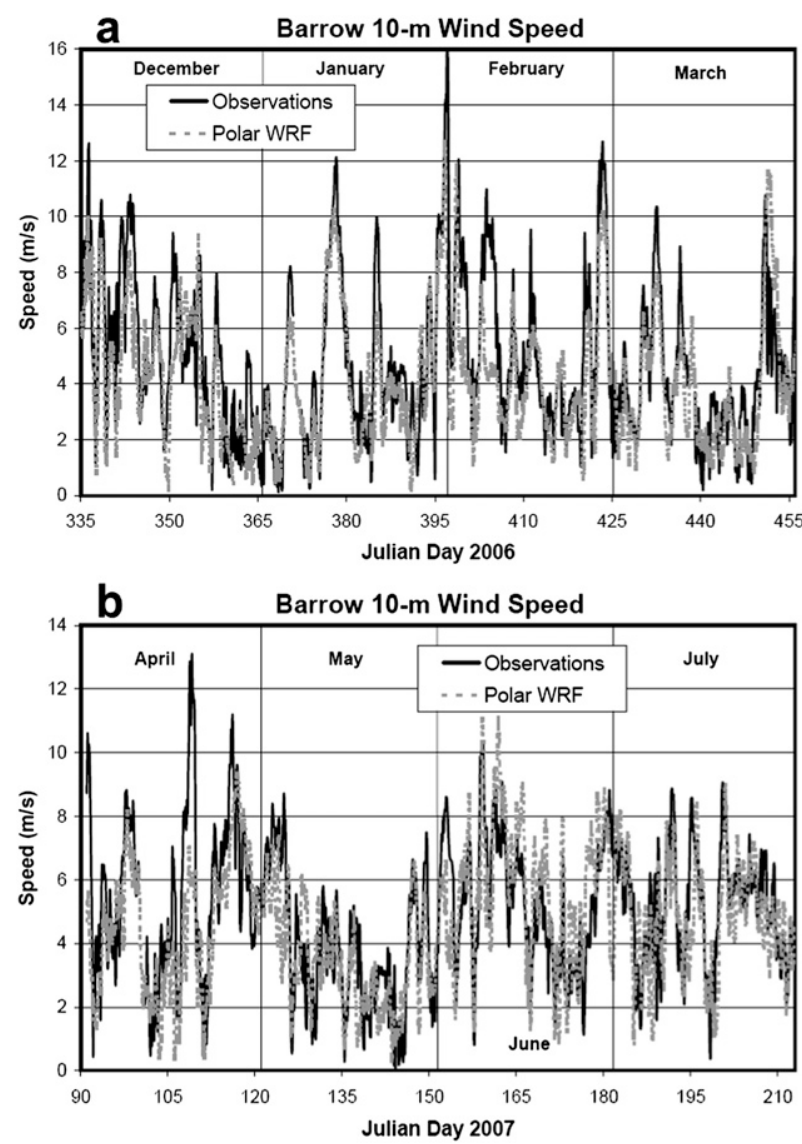

FIG. 5. Time series of $10-\mathrm{m}$ wind speed $\left(\mathrm{m} \mathrm{s}^{-1}\right)$ from observations (solid) at Barrow and the nearest Polar WRF land grid point (dashed).

increased solar insolation on the North Slope, we can expect increased temperature, increased sensible heat flux, and decreased latent heat flux there. This may explain some of the difference between the Polar WRF results for summer 2007 and Doran et al.'s (2006) heat fluxes from 1999 to 2001. The effect of soil moisture on the simulations will be discussed further in section 6 a.

As for the winter case, the overall warm bias from January to July (Fig. 3e; Table 2) is particularly large for the Bonanza Creek LTER sites during winter. The surface elevation of the nearest model grid point, $217 \mathrm{~m}$, is between that of LTER1 and LTER2. The biases are 4.0 and $3.9 \mathrm{~K}$ at the LTER1 ridge site during December and January, respectively. The biases are several degrees larger, 9.0 and $7.7 \mathrm{~K}$, respectively, for the colder LTER2 site in the Tanana River valley. Subgrid-scale topography influences the near-surface temperature in central Alaska. The observed temperature difference between the higher and lower altitudes is typical of the strong winter inversion for central Alaska (Shulski and Wendler 2007). Alaska weather forecasters view the combination of local topography and the near-surface temperature inversion as an especially difficult challenge. Polar WRF's warm bias there appears to be primarily a near-surface issue associated with the inversion rather than a more general bias, as the January bias in $850-\mathrm{hPa}$ temperature is only $0.6 \mathrm{~K}$ at Fairbanks, which is approximately one grid point east of the LTER sites.

WRF's difficulty simulating the intensity of the central Alaska inversion during midwinter was previously noted by Mölders and Kramm (2010). They simulated the temperature inversion for central Alaska during 27 January-2 February 2008. Their selection of physical parameterizations differed from those of this current study with Polar WRF. One of their cases, however, did employ the Noah LSM and had a systematic warm bias in near-surface temperature of about $3.5 \mathrm{~K}$. Correspondingly, simulated inversion strength was weaker than that observed. Mölders and Kramm (2010) note that the Monin-Obukhov similarity is incomplete for strongly stable boundary layers; therefore, parameterized near-surface turbulent fluxes can be expected to have limited accuracy for strong inversions.

\section{$b$. Wind speed and direction}

The model evaluation now considers wind speed at the NSA. Figure 5 shows time series of $10-\mathrm{m}$ wind speed for the observations at Barrow and at the nearest Polar WRF grid point. Observed wind speeds are also available from the top of the 5-m tower at Atqasuk, and these are compared to model wind speed at $10 \mathrm{~m}$ in Table 2. The wind speed results at the inland site show qualitatively similar seasonal patterns as the coastal site and are not discussed further. During winter and spring, the model qualitatively captures the variability of the wind speed at Barrow, with a few exceptions. Polar WRF fails to capture the maxima of 10.6 and $13.1 \mathrm{~m} \mathrm{~s}^{-1}$ on 1 and 19 April, respectively. Overall, Barrow tends to have higher observed maximum wind speeds than those represented by the model. The biases vary from -0.3 to $-1.2 \mathrm{~m} \mathrm{~s}^{-1}$ during the winter and spring months (Table 2). A consistent bias, however, is not found for the summer months. The seasonal difference in wind speed bias suggests that the model does not fully represent the change in surface roughness between the winter snow cover and summer vegetation.

Figure 6 shows time series of $10-\mathrm{m}$ wind direction at Barrow for January and July 2007. Wind direction is shown for wind speeds greater than $2 \mathrm{~m} \mathrm{~s}^{-1}$ with triangles for the observations and a dashed line for the model results. During January, the correlation, 0.87, is high for times when the speed exceeds $2 \mathrm{~m} \mathrm{~s}^{-1}$, both for observation and simulation. The mean meteorological wind direction for this winter month is from $97^{\circ}$ for the observations and from $104^{\circ}$ for the simulation. The RMSE is 

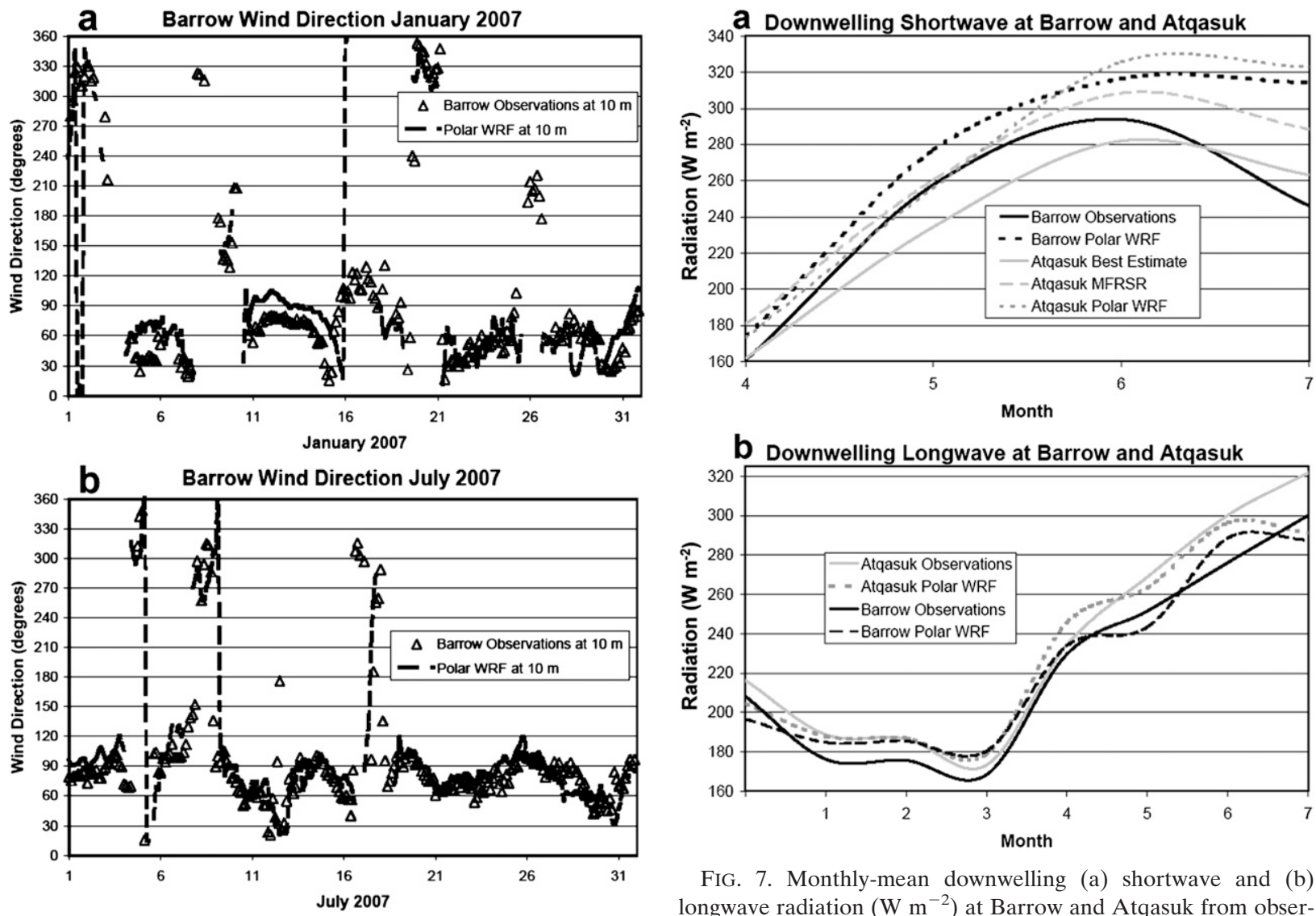

FIG. 7. Monthly-mean downwelling (a) shortwave and (b)

FIG. 6. Time series of $10-\mathrm{m}$ wind direction $\left(^{\circ}\right.$ ) for wind speed greater than $2 \mathrm{~m} \mathrm{~s}^{-1}$ from observations (triangles) at Barrow and the nearest Polar WRF land grid point (dashed) for (a) January and (b) July 2007 .

$46^{\circ}$. Polar WRF reasonably captures most synoptic wind direction shifts at Barrow for the winter month (Fig. 6a). During the summer month of July, the prevailing wind direction is from the east. For $84 \%$ of the time that the speed exceeds $2 \mathrm{~m} \mathrm{~s}^{-1}$, both the observed and simulated wind directions are between $30^{\circ}$ and $120^{\circ}$ (Fig. 6b). During these times the RMSE is $16^{\circ}$, and the mean direction is $80^{\circ}$ and $83^{\circ}$ for the observations and simulation, respectively. The prevailing direction of the observed 5-m wind at Atqasuk is also from the east during July. The simulated $10-\mathrm{m}$ wind for this inland site, however, has a northerly component and is turned $27^{\circ}$ compared to the observed 5 -m wind for this month.

\section{c. Incident radiation}

Figure 7 shows monthly means of downwelling longwave and shortwave fluxes at Barrow and Atqasuk. For most months, there is a positive bias in downwelling shortwave flux at the NSA (Fig. 7a). The observed values at Atqasuk from MFRSR are about $20 \mathrm{~W} \mathrm{~m}^{-2}$ or more longwave radiation $\left(\mathrm{W} \mathrm{m}^{-2}\right)$ at Barrow and Atqasuk from observations and Polar WRF simulation.

larger than the broadband downwelling shortwave best estimate values. The bias there for Polar WRF is negative during April and May compared to MFRSR and positive for all other months from February to July. The shortwave bias does not become large until June and July, when the bias becomes 22.6 and $68.1 \mathrm{~W} \mathrm{~m}^{-2}$, respectively, at Barrow. The bias at Atqasuk is 43.8 (17.2) and $59.8(34.6) \mathrm{W} \mathrm{m}^{-2}$ for those months in comparison to best estimate (MFRSR) observations, respectively. It is uncertain whether smoke from a record area-burned fire on the North Slope that began 16 July, a phenomenon not represented by Polar WRF, reduced the observed shortwave radiation (Jones et al. 2009). Soon we will explore why the shortwave bias becomes so large during summer.

Figure $7 \mathrm{~b}$ shows the monthly downwelling longwave flux for the NSA. Longwave radiation is important for all months, and the incident component at the surface has a minimum of $165-180 \mathrm{~W} \mathrm{~m}^{-2}$ during March before increasing to a summer maximum. The longwave bias is about $-12 \mathrm{~W} \mathrm{~m}^{-2}$ for both sites during December 2006, when the model simulates a cold bias compared to 2-m temperature observations (Table 2). The longwave bias is slightly positive, however, for most months prior 


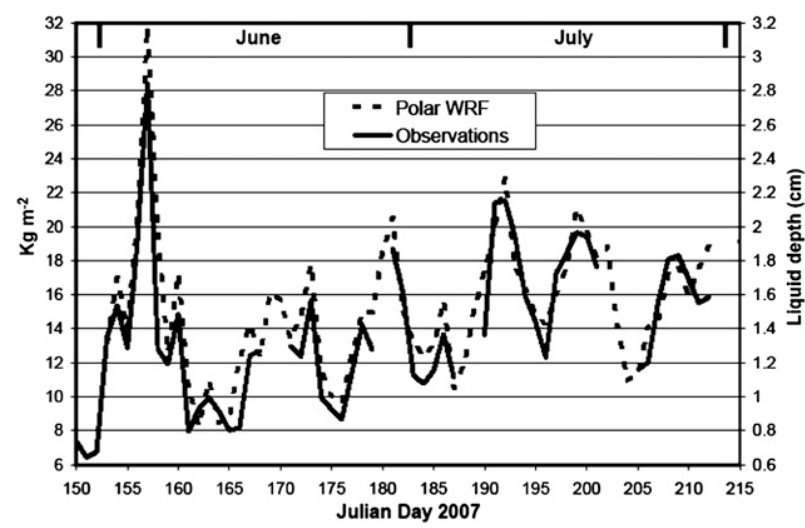

FIG. 8. Daily mean precipitable water vapor $\left(\mathrm{kg} \mathrm{m}^{-2}\right)$ at Barrow from observations and the Polar WRF simulation during June and July 2007. Upper tick marks show monthly boundaries.

to May. Largest magnitude biases have a negative sign and occur during July. The biases are -12.5 and $-30.6 \mathrm{~W} \mathrm{~m}^{-2}$ for Barrow and Atqasuk, respectively, during July. Given that the shortwave bias is positive for this month, the downwelling radiation suggests that Polar WRF simulates a deficit in cloud cover. The cloud deficit does not appear to occur because of a lack of total water vapor, as Fig. 8 shows very good agreement in daily average precipitable water vapor (the vertically integrated water vapor in an atmospheric column) between model results and observations at Barrow during June and July 2007. The averages at Barrow are 0.0128 (0.0143) m during June and 0.0157 (0.0163) m during July for the observations (Polar WRF). Fluctuations in the time series shown in Fig. 8 correspond to migrating cyclones and anticyclones over northern Alaska and the nearby Arctic Ocean, also influencing the surface pressure time series (Fig. 2b).

Polar WRF apparently does not sufficiently represent the frequent Arctic stratus during summer (e.g., Dong and Mace 2003). To demonstrate this, Fig. 9 shows time series of the LWP from Barrow observations and for the simulation at Barrow and Atqasuk. During June and July, the model simulates roughly similar amounts of LWP for both the land grid points near Barrow, along the coast, and near Atqasuk, about $100 \mathrm{~km}$ inland, although observations suggest the value should be larger for the latter (Doran et al. 2002, 2006). The observed LWP at Barrow shows similar magnitude as the simulation during June. The cloudy event between 10 and 15 June (Julian days 161-166) is reasonably well captured by the model (Fig. 9). Other synoptic events are less well captured, but they do not demonstrate an obvious and excessive bias for LWP during June.

A notable regime change in the local meteorology, however, occurs during summer and affects the observed

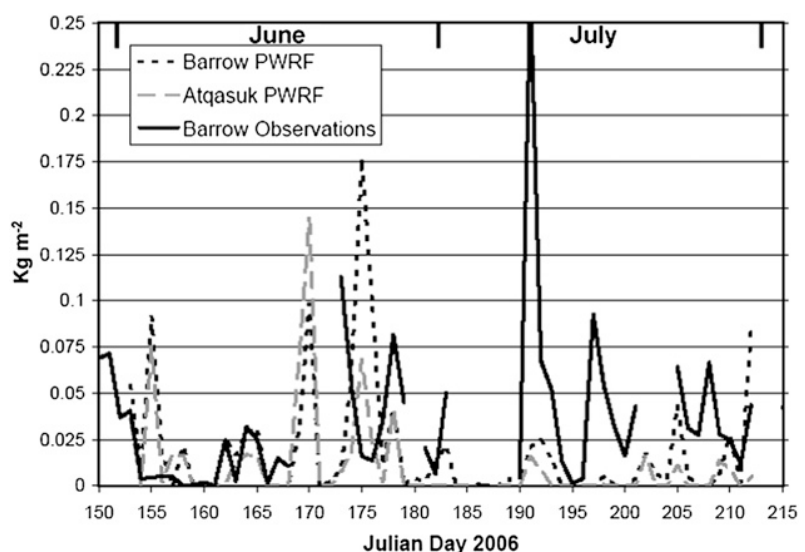

FIG. 9. Daily mean LWP $\left(\mathrm{kg} \mathrm{m}^{-2}\right)$ at the NSA from observations and the Polar WRF simulation during June and July 2007.

clouds. The pack ice (not shown) pulls away from the northern Alaska coast during early July, exposing large areas of open water to the atmosphere as summer progresses, eventually reaching the record-breaking minimum in sea ice coverage during late summer 2007. Several strong anticyclones over the nearby pack ice, especially on 14 and 27 June and 2 July (Fig. 2b), influenced the weather at Barrow. In contrast, anticyclones, while still episodically present, were much weaker after the sea ice retreat (Fig. 2b). Correspondingly, the observed overall cloud fraction is higher during July (Fig. 10). This is consistent with the observed seasonal increasing cloud fraction from spring until a maximum of about $90 \%$ that occurs during late summer at Barrow (Wendler and Eaton 1990; Walsh et al. 2009). The increase in observed cloud fraction in Fig. 10 was associated with increases in precipitable water vapor, cloud liquid water path, and incident

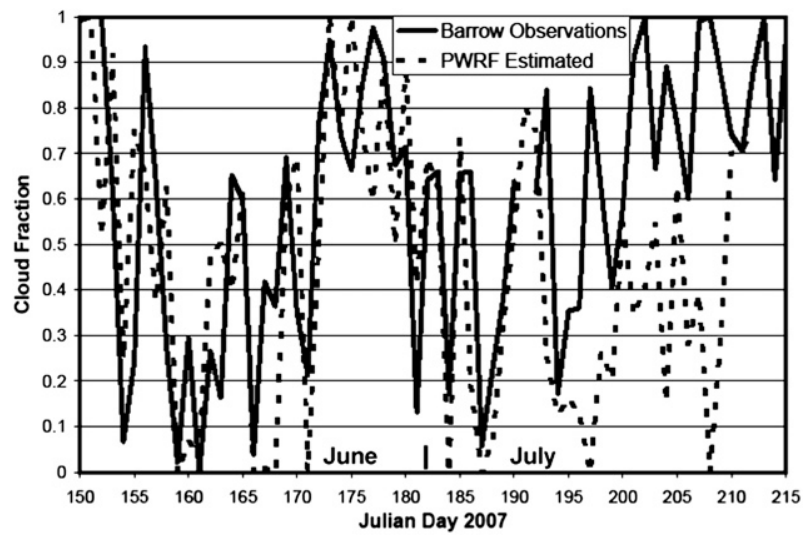

FIG. 10. Daily mean cloud fraction at Barrow from observations (solid) and simulation (dashed) during June and July 2007. The simulated values are estimated following Fogt and Bromwich (2008). 
longwave radiation (Figs. 7b, 8, and 9). The observed incident shortwave radiation also decreased (Fig. 7a). In the simulation of these events, Polar WRF incorporated the sea ice retreat through its lower boundary conditions and represented the increase in precipitable water vapor, but it did not simulate the observed effects on longwave and shortwave radiation.

Cloud fraction is not a standard output for WRF. An estimated value, however, can be obtained in the postprocessing from cloud liquid water and cloud ice amounts. Fogt and Bromwich (2008) use the equation

$$
\mathrm{CF}=C_{l} \times \mathrm{CLWP}+C_{i} \times \mathrm{CIWP}
$$

to estimate instantaneous cloud fraction $\mathrm{CF}$ at McMurdo, Antarctica, from AMPS results. CLWP and CIWP are cloud liquid water path and cloud ice water path, respectively. Fogt and Bromwich (2008) found closest agreement to observations when the weighting coefficients $C_{l}$ and $C_{i}$ had the values 0.075 and $0.170 \mathrm{~m}^{2} \mathrm{~kg}^{-1}$, respectively, rather than those from an earlier formula, 0.100 and $0.0735 \mathrm{~m}^{2} \mathrm{~kg}^{-1}$, respectively, which was not optimized for polar environments. We apply Fogt and Bromwich's formula to Polar WRF output. This results in monthly averaged cloud fractions for Polar WRF that are relatively larger by $10 \%-20 \%$ than those from the older formula at Barrow. The estimated monthly averaged cloud fraction for the simulation is 0.49 at Barrow for June, very close to the observed 0.51. During July, however, the simulated value is 0.37 , while the observed value is 0.63 . The difference is very apparent in Fig. 10 after 12 July, when the observed daily cloud fraction almost always exceeds the estimate from the simulation. Much of oversimulation of incident solar radiation can be attributed to a deficit in cloud fraction.

\section{Sensitivity experiments}

\section{a. Cloud microphysics and boundary layer parameterization}

In response to these summertime results for clouds and radiation in the standard Polar WRF run, we experiment with different convection, boundary layer, and microphysics schemes within the WRF suite of options. Initial testing showed little sensitivity to the convection scheme; however, some sensitivity was suggested for other physics parameterizations. Therefore, alternative simulations for July 2007 were performed. Especially relevant during this period is the latter half of July when there is a large difference in cloud fraction between the simulation and observations (Fig. 10). The new sensitivity simulations consider the Yonsei University (YSU) boundary layer scheme and the WRF Single-Moment 6-Class microphysics scheme (WSM6C) as replacements for the MYJ and Morrison schemes, respectively. Four new simulations are performed. The first three have changes to the model physics, including the following: (i) the YSU scheme, (ii), the WSM6C scheme, and (iii) the YSU and WSM6C schemes.

A fourth simulation, referred to as "moist soil," is also performed. It employs the MYJ and Morrison schemes, as in the standard simulation it is referred to as the "control." The new simulation explores the possibility that a deficit in available surface moisture for the NSA tundra regions contributes to the limited cloud cover and excessive incident shortwave radiation. For the initial conditions of the 48-h segments of moist soil, the moisture in the top two soil layers (top $0.4 \mathrm{~m}$ ) is multiplied by 1.5 for tundra land use types north of $68^{\circ} \mathrm{N}$ between $165^{\circ}$ and $140^{\circ} \mathrm{W}$ where the surface elevation is below $1000 \mathrm{~m}$. This area approximates the region of Alaska north of the Brooks Range. Added soil moisture is unfrozen, and an upper limit of 0.4 is placed beyond which soil moisture fraction is not increased. Saturation is typically achieved at soil moisture fractions near 0.43 for tundra in the Noah LSM. During the simulations, the average July soil moisture fraction in the top layer of the affected area is 0.21 in the control and 0.27 in moist soil. The expected loss due to increased evaporation during moist soil acts to reduce the difference in soil moisture between simulations. The initial conditions for both the atmosphere and the soil in the July sensitivity tests are otherwise identical to the control. The sensitivity simulations and the control consist of a series of 48-h segments begun daily at 0000 UTC.

Figure 11 shows bar graphs of average downwelling shortwave and longwave radiation during July for Barrow and Atqasuk. Averages for the observations and the sensitivity simulations are also given in Table 3 . The model results labeled as "ocean point" are from the model's grid point over the Arctic Ocean that is closest to Barrow. There is a striking difference between the grid points over ocean and land for both longwave and shortwave radiation, with higher values for the former and much smaller values for the latter at the ocean point, indicating more extensive cloudiness there. At that point, the control has average longwave and shortwave fluxes of 299.0 and $241.2 \mathrm{~W} \mathrm{~m}^{-2}$, respectively. Both the YSU and the WSM6C decrease the shortwave radiation and increase the longwave radiation near Barrow. The biggest effect is in the combined experiment YSU+WSM6C at ocean point, with monthly average longwave and shortwave fluxes of 306.1 and $186.6 \mathrm{~W} \mathrm{~m}^{-2}$, respectively. Interestingly, the control produces results at ocean point that are closest to the observations along the coast at Barrow. The results show that the selection of boundary layer scheme and 

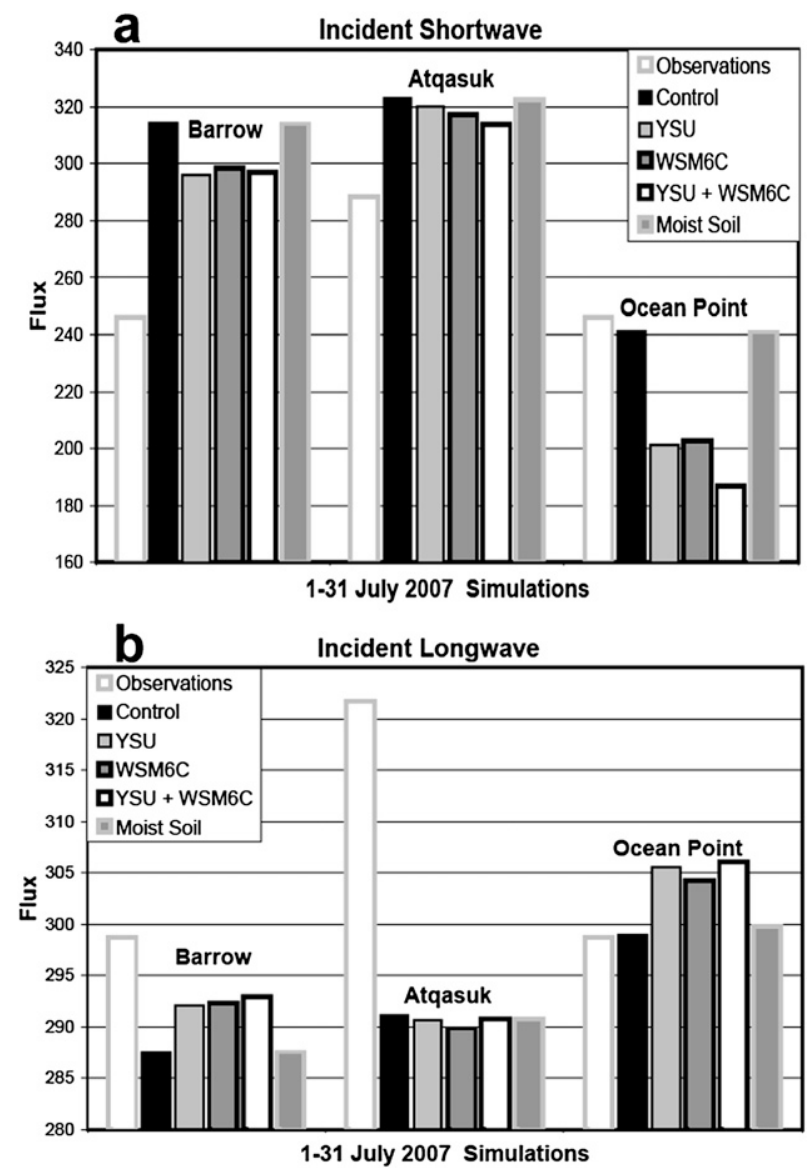

FIG. 11. Bar graphs of average downwelling (a) shortwave and (b) longwave radiation $\left(\mathrm{W} \mathrm{m}^{-2}\right)$ for 1-31 Jul 2007 near Barrow and Atqasuk from observations, control simulation, and sensitivity experiments. Model results for "Barrow" are from a land grid point. Ocean point is the adjacent grid point to the north.

microphysics scheme has a very large effect on the simulation of Arctic stratus over the Arctic Ocean.

In contrast over land, which is emphasized here, simulated inland values at Atqasuk range from 289.9 to $291.1 \mathrm{~W} \mathrm{~m}^{-2}$ and from 313.8 to $323.0 \mathrm{~W} \mathrm{~m}^{-2}$ for longwave and shortwave, respectively, in the physics sensitivity tests. Thus, there is small sensitivity to the physics schemes over land. Moreover, the agreement with the observed fluxes at Atqasuk is poor in Table 3. The errors are approximately $30 \mathrm{~W} \mathrm{~m}^{-2}$ for longwave and $30-60 \mathrm{~W} \mathrm{~m}^{-2}$ for shortwave at the inland site. The model grid point over land near Barrow is close enough to the ocean so that the selection of physics schemes has a moderate effect on the incident radiation there, with the physics sensitivity simulations showing results somewhat closer to the observed values (Fig. 11). Nevertheless, the physics changes have not solved the inland bias for downwelling radiation. The excessive downwelling shortwave radiation and deficit in downwelling longwave radiation indicate a summertime deficit in clouds over land. Estimated July cloud fraction at Atqasuk is only 0.27 in the control. In contrast, the corresponding value is 0.78 at the ocean point. Dry conditions over land can correspond to large simulated Bowen ratio, discussed in section 5a.

Doran et al. (2006) note that latent heat flux over tundra is important for the generation of summer stratus. The large simulated Bowen ratio, thus the dominance of sensible over latent heat flux, suggests that the modeled tundra may be too dry, thereby reducing evaporation that could supply moisture for land-based stratus and leading to biases in the radiation fields. The sensitivity experiment moist soil considers the effect of increased soil moisture at the NSA. Latent heat fluxes during July (not shown) were $15-20 \mathrm{~W} \mathrm{~m}^{-2}$ larger in moist soil than the control, leading to a corresponding decrease in sensible heat flux and a slight reduction in skin temperature (less than $1 \mathrm{~K}$ ). Table 3 and Fig. 11, however, show that the increased soil moisture induced little change in shortwave and longwave fluxes at Barrow and Atqasuk. Estimated cloud fractions were similar in moist soil and the control. Therefore, the NSA cloudiness showed surprisingly little sensitivity to soil moisture. Similar to this regional modeling deficiency, Walsh et al. (2009) find that a large negative bias in summertime cloud fraction over Arctic land is a persistent problem for current-generation global reanalyses.

TABLE 3. Average incident radiation from observation at Barrow and Atqasuk and Polar WRF simulations for 1-31 Jul 2007. Shortwave observed values at Atqasuk are from the "best available" and MFRSR observations with the latter in parenthesis. The ocean point is the Polar WRF grid point over the Arctic Ocean closest to Barrow. The sensitivity simulations can include the YSU planetary boundary layer scheme and the WSM6C scheme. The simulation moist soil has increased moisture in the upper two soil layers of the Noah LSM.

\begin{tabular}{|c|c|c|c|c|c|c|}
\hline Station & Observations & Control & YSU & WSM6C & YSU+WSM6C & Moist soil \\
\hline \multicolumn{7}{|c|}{ Incident longwave } \\
\hline Barrow & 298.7 & 287.6 & 292.1 & 292.3 & 292.9 & 287.6 \\
\hline Ocean point & - & 299.0 & 305.6 & 304.3 & 306.1 & 299.8 \\
\hline Atqasuk & 321.7 & 291.1 & 290.7 & 289.9 & 290.8 & 287.0 \\
\hline \multicolumn{7}{|c|}{ Incident shortwave } \\
\hline Barrow & 246.1 & 314.3 & 296.3 & 298.4 & 297.3 & 314.2 \\
\hline Ocean point & - & 241.2 & 201.1 & 202.5 & 186.6 & 241.0 \\
\hline Atqasuk & $263.2(288.4)$ & 323.0 & 320.0 & 317.2 & 313.8 & 322.5 \\
\hline
\end{tabular}


In the present study, the deficit in summer clouds over Arctic land may be related to the vertical profile of relative humidity. Figure 12 shows profiles of temperature and relative humidity for July 2007 at Barrow. The observed profiles are based upon standard-level observations, so the detailed temperature structure in the simulated profile below $850 \mathrm{hPa}$ is not displayed for the observed field in Fig. 12a. While the temperature profile above the boundary layer is very well captured by the simulation, the simulated relative humidity profile does not demonstrate the strong vertical gradient of relative humidity in the observations. Figure $12 \mathrm{~b}$ may indicate that excessive mixing of water vapor in the vertical may inhibit the concentration of the moisture into low clouds. Improved boundary layer parameterizations may be required for an improved cloud simulation.

\section{b. Tundra heat transfer}

In response to the winter warm bias for near-surface temperature, another sensitivity experiment was conducted with Polar WRF. The motivation was partly based upon independent work toward the production of the ASR with an Arctic-enhanced Noah LSM (Bromwich et al. 2010). That work suggests improved results can be obtained with the implementation of an organic upper soil layer. Correspondingly, in a study of soil thermal properties, Ling and Zhang (2004) noted a 0.16-m-thick peat layer present at Barrow with reduced heat conductivity in comparison to other soil types. Furthermore, Lawrence and Slater (2008) note the widespread presence of organic soil in the Arctic tundra. They assign a small heat conductivity, $0.25 \mathrm{~W} \mathrm{~m}^{-1} \mathrm{~K}^{-1}$, to peat and note that organic matter acts as an insulator that reduces soil cooling during winter and fall.

During midwinter, the average heat flux in the control experiment from the commonly warmer soil to the commonly colder lower atmosphere appears to be excessive for the Alaska sites. January model values include $16 \mathrm{~W} \mathrm{~m}^{-2}$ at Barrow, $15 \mathrm{~W} \mathrm{~m}^{-2}$ at Atqasuk and Bonanza Creek, $9 \mathrm{~W} \mathrm{~m}^{-2}$ at West Kuparuk, and $14 \mathrm{~W} \mathrm{~m}^{-2}$ at Kougarok. Values for February are even larger, more than $30 \mathrm{~W} \mathrm{~m}^{-2}$ in some cases. Excessive heat flux upward from the warmer soil, which contributes to heating the atmosphere, is consistent with a modeled warm bias in winter atmospheric temperature, as seen in Table 2.

Ling and Zhang (2006) provide representative values of heat flux between atmosphere and winter snowpack at Barrow for 1997/98. About $0.4 \mathrm{~m}$ of snow is present during that winter. They estimate the average heat flux in the range of 3.5-7.5 $\mathrm{W} \mathrm{m}^{-2}$ for December and January. The flux for February and March is smaller, less than $4 \mathrm{~W} \mathrm{~m}^{-2}$. The GFS final analysis data from 2007, the
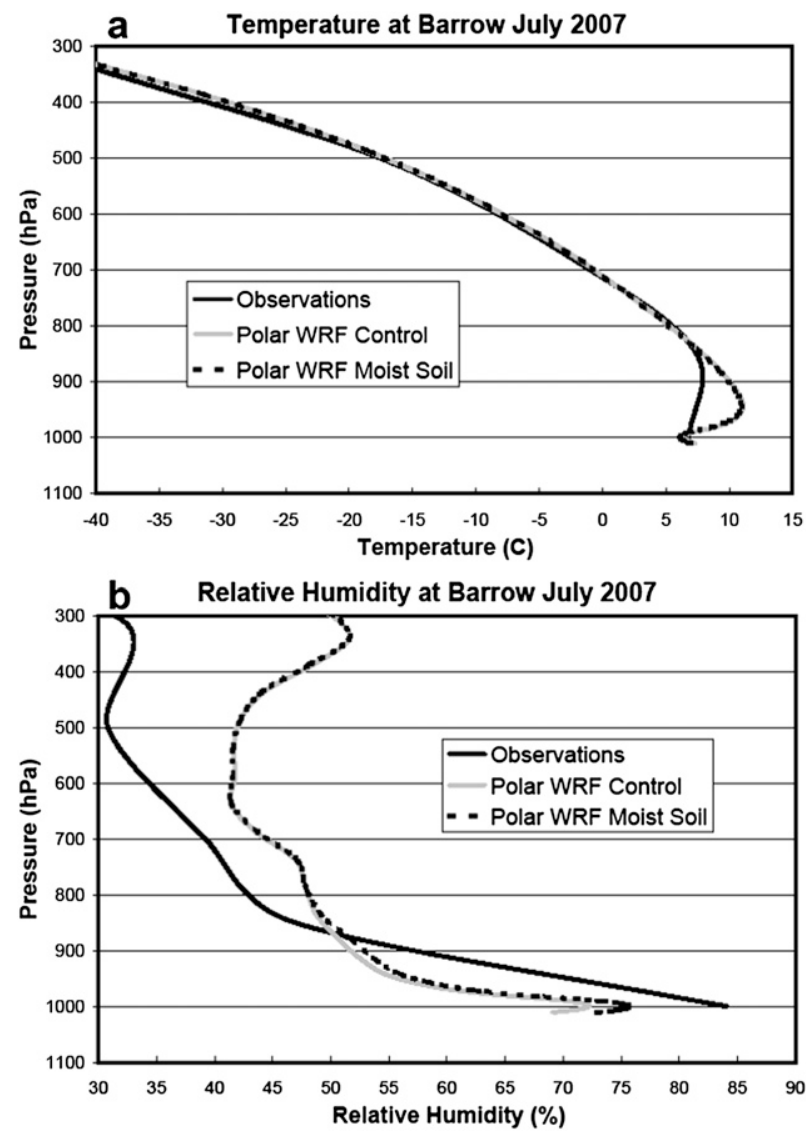

FIG. 12. Vertical profiles of (a) temperature $\left({ }^{\circ} \mathrm{C}\right)$ and (b) relative humidity (fraction) at Barrow for July 2007. Solid black line shows observations, solid gray line shows the control simulation, and dashed line is the moist soil simulation.

same data used for the Polar WRF initial conditions, suggest $0.15-0.25 \mathrm{~m}$ of snow is present during midwinter near Barrow and Atqasuk. Given the thinner snowpack, a heat flux about twice Ling and Zhang's (2006) estimates is reasonable for January 2007. By comparison, the model values reported above may be excessive.

A sensitivity experiment was performed with the heat conductivity modified for tundra land use types within the domain. The experiment takes the upper 0.1-m layer of tundra as an organic soil layer. Specifically, thermal conductivity is reduced by an order of magnitude to $0.25 \mathrm{~W} \mathrm{~m}^{-1} \mathrm{~K}^{-1}$ for heat flux between the surface and the upper soil layer prior to weighted averaging with the conductivity of the snow cover layer. The net conductivity $C$ is obtained from

$$
C=\left(C_{\text {snow }} h_{\text {snow }}+C_{\text {soil }} h_{\text {soil }}\right) /\left(h_{\text {snow }}+h_{\text {soil }}\right),
$$

where $C_{\text {snow }}$ and $C_{\text {soil }}$ are heat conductivities of snow and soil, respectively, and $h_{\text {snow }}$ and $h_{\text {soil }}$ are the depths 

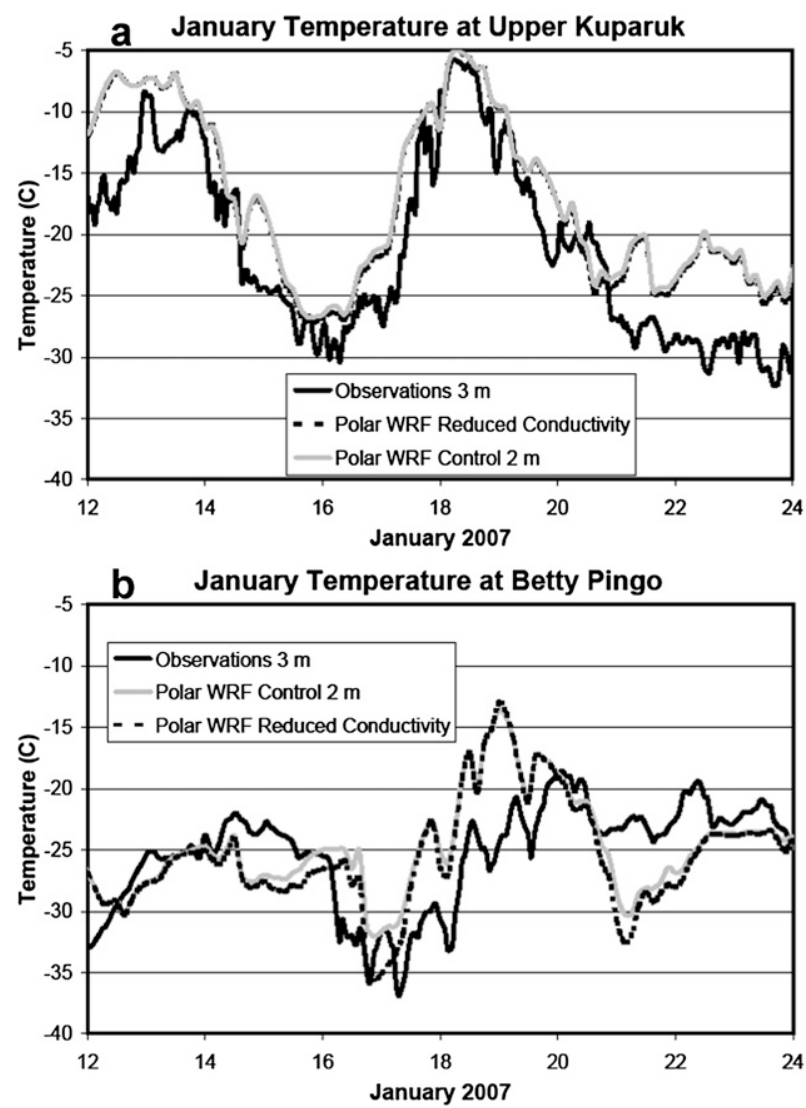

FIG. 13. Time series of atmospheric temperature $\left({ }^{\circ} \mathrm{C}\right)$ at (a) Upper Kuparuk and (b) Betty Pingo from observations at $3 \mathrm{~m}$ and Polar WRF simulations at $2 \mathrm{~m}$ for 12-24 Jan 2007. Includes the Polar WRF sensitivity test with reduced conductivity for upper soil layer.

of snow and the upper soil layer, respectively. The averaging of $C_{\text {soil }}$ and $C_{\text {snow }}$ tends to reduce the net conductivity from the soil value because of strong insulation by snow. In the sensitivity experiment, the new upper soil layer conductivity, $0.25 \mathrm{~W} \mathrm{~m}^{-1} \mathrm{~K}^{-1}$, has some influence on heat flux between the upper layer and the $0.3-\mathrm{m}$ thick layer directly below it, although the conductivity setting was not changed for the three lowest of the four Noah soil layers.

The sensitivity experiment applies the changes for a 13-day rerun between 11 and 24 January 2007. New output values for soil temperature and soil moisture from the individual 48-h step integrations were cycled into the initial conditions of subsequent runs according to the procedure described in section 3 . The original simulation with the standard soil heat conductivity is again referred to as the "control."

Figures 13-15 show results from the sensitivity simulation. In Fig. 13, atmospheric 2-m temperature at Betty Pingo and Upper Kuparuk responds to the reduced conductivity of the upper soil layer for the first experiment by

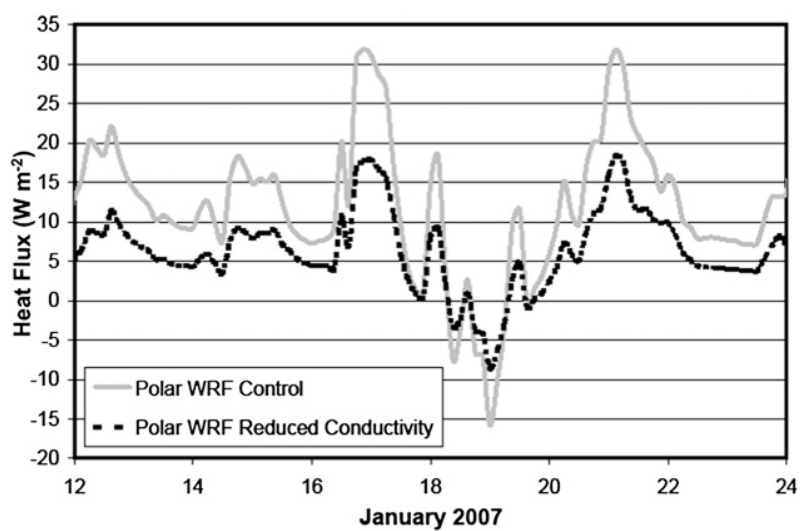

FIG. 14. Time series of ground heat flux $\left(\mathrm{W} \mathrm{m}^{-2}\right)$ at Betty Pingo from Polar WRF simulations for 12-24 Jan 2007, including the control (gray) and the sensitivity test with reduced conductivity for the upper soil layer (dashed).

showing lower values during the colder events during the test period, especially 17 and 21 January at Betty Pingo. On 17 January, the minima are $-32.1^{\circ} \mathrm{C}$ for the control and $-35.6^{\circ} \mathrm{C}$ for the sensitivity experiment with reduced conductivity. Similar temperature results for the two experiments are found for Barrow and Atqasuk (not shown). In contrast, the minimum is only reduced by $0.4^{\circ} \mathrm{C}$ to $-27.1^{\circ} \mathrm{C}$ by the change in conductivity at the warmer site Upper Kuparuk (Fig. 13a). On the other hand, the changes have very little effect on temperature at either Betty Pingo or Upper Kuparuk during warmer events.

Figure 13 shows that Polar WRF only approximately captures the structure of warmer and colder events during January in the Kuparuk area. The difference between the model and the observation is as large as $11 \mathrm{~K}$ on 19 January at Betty Pingo. The model, however, does demonstrate a large contrast between the sites for the northern and southern Kuparuk Valley, similar to the observed difference, especially for 12-14 and 18 January. The large temperature difference between Betty Pingo and Upper Kuparuk corresponds to the complicated synoptic and mesoscale conditions over northern Alaska during January 2007. Given this complexity, the model results displayed in Fig. 13 can be viewed favorably, as Polar WRF approximately represents local baroclinity in the Kuparuk area. Moreover, the enhanced cold extremes in the sensitivity experiment are taken as an improvement upon a model warm bias during winter when strong temperature inversions are frequent.

Figure 14 shows the heat flux at Betty Pingo between the model's upper soil layer and the surface, referred to as ground heat flux. It is given as positive when directed upward and having the effect of heating the surface. As stated earlier, we suspect the average ground heat flux is too large in the control simulation with Polar WRF. The 


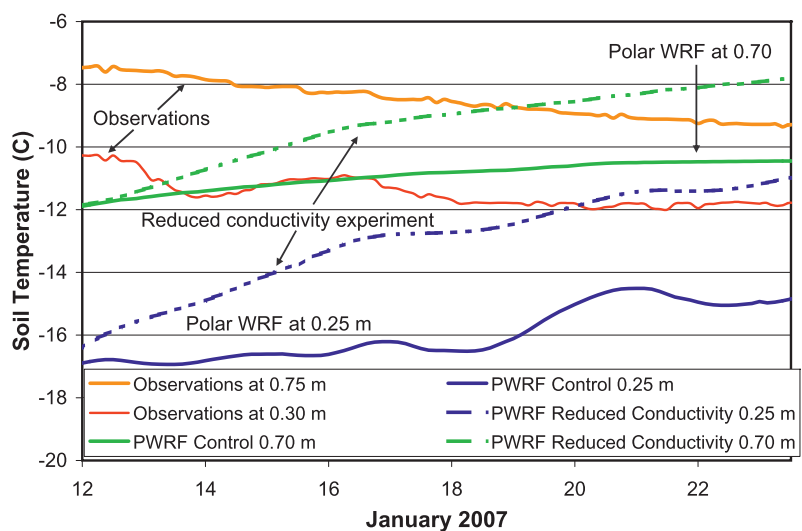

FIG. 15. Time series of soil temperature $\left({ }^{\circ} \mathrm{C}\right)$ at Betty Pingo from observations (red and orange) at 0.30 - and 0.75 -m depth and Polar WRF simulations at 0.25 - (blue) and $0.70-\mathrm{m}$ (green) depth for 12-24 Jan 2007. Includes Polar WRF control (solid) and sensitivity test with reduced conductivity (dash-dotted).

sensitivity experiment with reduced conductivity, however, shows improvement, as the heat flux is much reduced during positive maxima. Interestingly, changing the heat conductivity has less effect during warm events when the ground heat flux has smaller values. This is consistent with the effect of the conductivity change seen for cold extrema but not warm extrema in Fig. 13.

The sensitivity experiment also alleviates a cold bias in soil temperature at Betty Pingo (Fig. 15). In the control simulation, modeled temperature at $0.25-$ and $0.70-\mathrm{m}$ depth is colder than the observations at 0.30 - and $0.75-\mathrm{m}$ depth. The difference is characteristic of excessive heat exchange between the soil and the frequently colder atmosphere during midwinter. As seen in Fig. 14, heat flux is reduced in the sensitivity experiment, and this prompts the modeled $0.70-\mathrm{m}$ depth temperature to eventually exceed the observed value at $0.75 \mathrm{~m}$ by $1 \mathrm{~K}$. Furthermore, while the observed temperature shows the gradual seasonal temperature decrease, the experiment's temperature at $0.25-\mathrm{m}$ depth warms by about $4 \mathrm{~K}$ in comparison to the control and becomes slightly warmer than the observed $0.30-\mathrm{m}$ depth temperature by the end of the test period.

Table 4 shows $0.25-\mathrm{m}$ depth soil temperature results for several stations, including Betty Pingo. These stations were selected based upon quality control of observations. Part of the quality control involved selecting sites with temperature differences of several degrees between observations at higher and lower levels, as that provides better comparisons with the vertically varying simulated temperatures. Observed values are interpolated to $0.25 \mathrm{~m}$ where necessary. Table 4 shows an overall cold bias for the simulated temperature for 12-24 January in the control. In contrast, for the sensitivity experiment, the sign of the January
TABLE 4. Average soil temperatures $\left({ }^{\circ} \mathrm{C}\right)$ at 0.25 -m depth from observation and Polar WRF simulation for 12-24 Jan. Biases are shown in parenthesis. All biases are significant at the $99 \%$ confidence level, except for the control at Sagwon Hill, which is significant at the $95 \%$ confidence level.

\begin{tabular}{lccc}
\hline \hline \multicolumn{1}{c}{ Site } & Obs & $\begin{array}{c}\text { Control } \\
\text { simulation }\end{array}$ & $\begin{array}{c}\text { Reduced } \\
\text { conductivity expt }\end{array}$ \\
\hline Betty Pinto & -11.5 & $-15.9(-4.4)$ & $-12.9(-1.4)$ \\
Franklin Bluff & -14.1 & $-15.0(-0.9)$ & $-12.3(1.8)$ \\
Sagwon Hill & -11.9 & $-12.3(-0.4)$ & $-10.5(1.4)$ \\
Upper Kuparuk & -5.5 & $-8.4(-2.9)$ & $-7.5(-2.0)$ \\
Kougarok & -4.1 & $-2.0(2.1)$ & $-1.4(2.7)$ \\
\hline
\end{tabular}

biases vary between sites. Average bias is $-1.3 \mathrm{~K}$ for the control and $0.5 \mathrm{~K}$ for the sensitivity experiment. Overall, the sensitivity experiment with reduced conductivity improves the representation of winter climate for Alaska, as reduced heat conductivity in the upper soil alleviates a warm bias in atmospheric near-surface temperature, reduces excessive ground heat flux, and reduces a cold bias in soil temperature. The use of organic soil characteristics for the Arctic is planned for the ASR.

\section{c. Spring snowmelt}

In the control experiment, Polar WRF was based upon WRF version 3.0.1.1 and the snow albedo was specified at 0.8 for premelt conditions and 0.7 for summer conditions with a 5-day transition in between. Since it would be preferable to have a snow hydrology treatment within the model that does not require user input on the timing of snowmelt, an additional sensitivity test is performed. The new simulation employs Polar WRF based upon the more recent WRF version 3.1.1. The new version has improvements to the snow hydrology, including a predictive snow albedo based upon Livneh et al. (2010) that can range as high as 0.85 . The improvements were designed to better capture snow characteristics during spring snowmelt. We now test Polar WRF 3.1.1 for spring snowmelt over the NSA. The new sensitivity experiment has identical initial conditions for the 48-h segments as the control. For each segment, the initial snow depth is obtained from the GFS. The sensitivity experiment is run for 10 May-10 June 2007.

Figure 16 shows the day-to-day progression of surface albedo after $24 \mathrm{~h}$ of simulation for Barrow and Atqasuk. At Barrow, the observed albedo stays large until steadily decreasing beginning the first few days of June (Fig. 16a). Polar WRF 3.1.1 represents a mean value above 0.8 prior to the onset of snowmelt. Observed values fluctuate during May mostly within the range of observational accuracy. There is a minima near 0.71 on 25 May (Julian day 145 ) not captured by the simulations. The observed value 


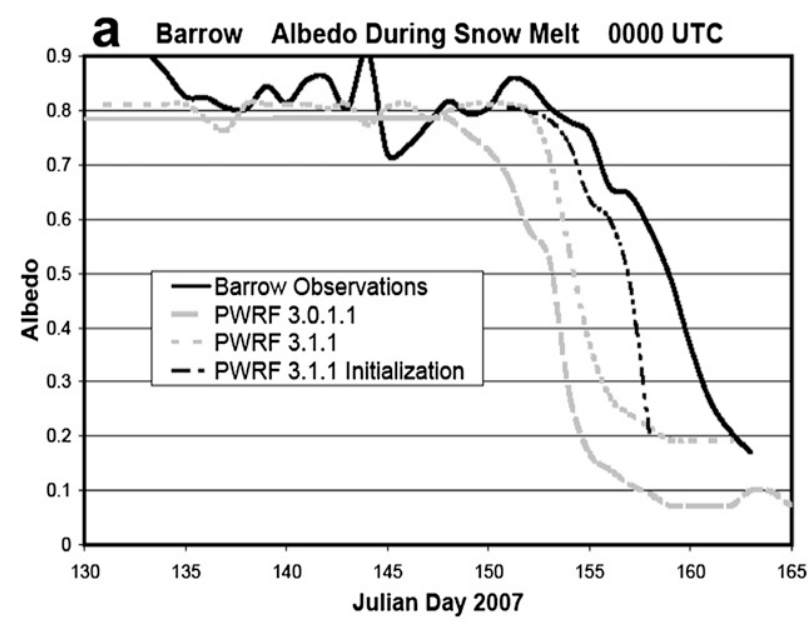

b Atqasuk Albedo During Snow Melt 0000 UTC

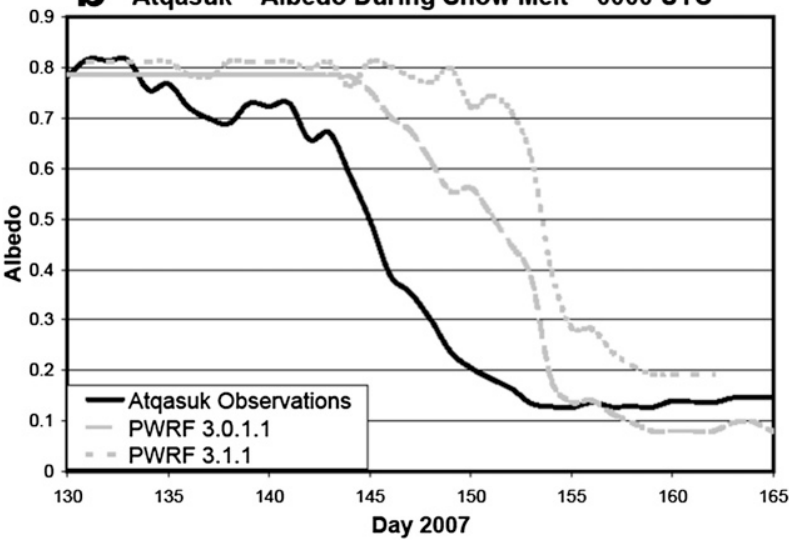

FIG. 16. Time series of albedo for (a) Barrow and (b) Atqasuk during the spring snowmelt period. Thick solid lines are observations. Incident shortwave radiation at Atqasuk for albedo calculations is from the best estimate value. Dashed gray lines represent the control simulation with Polar WRF 3.0.1.1. Dotted gray lines represent the sensitivity simulation for 10 May-10 Jun 2007 with Polar WRF 3.1.1. The dash-dotted thin line in (a) is the hour 0 values for Polar WRF 3.1.1 during 31 May-7 Jun. All other model values are for 24-h simulations.

steadily declines in June until falling below 0.2 on 11 June. The albedo and associated snowpack decay quicker in the simulations. The decay, however, is slower by a few days in Polar WRF 3.1.1 than in Polar WRF 3.0.1.1. Results at Sagwon Hills (not shown) are similar to those at Barrow, with the simulations displaying a rapid decay in the albedo faster than that of the observations, although the Polar WRF 3.1.1 albedo was somewhat closer to the observed value. The initial albedo (hour 0 simulation) at Barrow for Polar WRF 3.1.1 is also shown in Fig. 16a. Without the snow alterations that occur during the first $24 \mathrm{~h}$ of a simulation, the albedo is larger in early June and closer to the observed value. This indicates that snow is melting too rapidly, with extensive melting occuring within the first $24 \mathrm{~h}$ of a segment. Nevertheless, Polar WRF 3.1.1 is an improvement over Polar WRF 3.0.1.1 at Barrow.

At Atqasuk, a different pattern is apparent (Fig. 16b). Here best estimate values of incident solar flux are used to calculate the observed albedo. Snowmelt and albedo decay earlier here than at Barrow, with evidence for snowmelt affecting albedo by 21 May (Julian day 141). The observed albedo decays 5-10 days faster than simulated values. As in Fig. 16a, the albedo decays more quickly for Polar WRF 3.0.1.1, although the same initial snow cover is used with Polar WRF 3.1.1. Figure 16b suggests that the model simulations include excessive initial snow cover at Atqasuk during late May and early June. The different model biases that appear between Figs. 16a and 16b could be due to subgrid-scale distributions of snow cover, or it could be due to the difficulties in obtaining accurate distributions of snow cover in the observed record. Nevertheless, Polar WRF 3.1.1 with a predicted snow albedo was not generally less successful than Polar WRF 3.0.1.1 with a more prescribed snow albedo treatment. The Polar WRF 3.1.1 version is therefore preferable for convenience of the user, as prescribing the seasonality of snow albedo is not required.

\section{Conclusions}

Polar WRF is tested over the western Arctic in comparison to observations from Alaska, with emphasis on the North Slope region, for the simulation period from 15 November 2006 to 1 August 2007. The evaluation represents the third stage in a three-stage series testing Polar WRF for the climate over (i) permanent ice sheet surfaces, (ii) polar ocean and sea ice, and (iii) Arctic land. This work also represents a step toward the Arctic System Reanalysis that will provide a high-resolution depiction of Arctic climate for the years 2000-10. Polar WRF has previously been shown to provide an improved regional climate model for several Arctic and Antarctic applications. In the current study, simulations based upon WRF version 3.0.1.1 with added polar optimizations are compared to land observations from (i) the ARM NSA in north-central Alaska, including the coastal site Barrow and inland site Atqasuk; (ii) the Kuparuk area WERC meteorological data from northeastern Alaska; (iii) LTER data from Bonanza Creek in central Alaska; and (iv) WERC Arctic Transitions in the Land-Atmosphere System (ATLAS) data from the Seward Peninsula in western Alaska (Table 1).

The simulations have $25-\mathrm{km}$ horizontal resolution and 28 levels in the vertical. Polar WRF has improvements to the Noah land surface model and sea ice treatment from Hines and Bromwich (2008) and Bromwich et al. (2009). 
Simulations consist of a series of 48-h integrations initialized daily at 0000 UTC. For the atmosphere, the initial $24 \mathrm{~h}$ are taken as spinup for hydrology and boundary layer processes from initial fields supplied by the GFS final analysis. Soil temperature and moisture, which have a much slower spinup than the atmosphere, are cycled from 48-h output of earlier runs, effectively providing a continuous simulation over several months.

Overall, Polar WRF simulation results show good agreement with most near-surface observations. Simulations of 10-m wind speed show a slight negative bias at the NSA until the snowmelt in late May leads to a regime change with the onset of summer conditions. An overall warm temperature bias is found for winter. The bias is larger in the Kuparuk River basin and at the LTER sites in central Alaska than at the ARM sites Barrow and Atqasuk. Temperature biases are small in western Alaska at Kougarok and Council. A sensitivity experiment during January 2007 with reduced soil heat conductivity representative of organic Arctic soil simulates improvements for both the soil and near-surface atmosphere. The change reduces excessive ground heat flux, resulting in colder near-surface atmospheric temperature during colder events, and alleviates a cold bias in soil temperature. Future versions of WRF and the Noah LSM are under development that may provide improved Arctic land representations. As an example, the snow albedo treatment that is available with Noah in WRF 3.1.1, but unavailable for the simulations here with Polar WRF 3.0.1.1, produced favorable results in a sensitivity simulation of NSA surface albedo during the spring melt season.

The control simulation is also found to have an overall summer warm bias. Monthly downwelling longwave and shortwave radiation appear reasonable during winter and spring. During summer, especially July, the modeled radiation fields over land are biased by an apparent underrepresentation of the frequently observed Arctic stratus clouds. The cloud and radiation fields over the nearby Arctic Ocean are found to be highly sensitive to the selection of microphysics and boundary layer scheme. Little sensitivity, however, is found inland at Atqasuk. It is suggested here that improved boundary layer parameterizations with better treatment of vertical moisture mixing in the lower troposphere may alleviate the cloud bias.

Acknowledgments. This research is supported by NSF IPY Grants ARC-0733023, ARC-0733058, and ARC0732986, DOE Award GRT00008066, and UCAR Subcontract S01-22961. We thank Hugh Morrison for his helpful comments on Arctic clouds, and Hans Verlinde and Mark Anderson for their data contributions. The WRF simulations were performed with Grant PAS0400 from the Ohio Supercomputer Center, which is supported by the state of Ohio.

\section{REFERENCES}

Ackerman, T., and G. Stokes, 2003: The Atmospheric Radiation Measurement Program. Phys. Today, 56, 38-45.

Barker, D. M., W. Huang, Y.-R. Guo, A. J. Bourgeois, and Q. N. Xiao, 2004: A three-dimensional variational data assimilation system for MM5: Implementation and initial results. Mon. Wea. Rev., 132, 897-914.

Bromwich, D. H., J. J. Cassano, T. Klein, G. Heinemann, K. M. Hines, K. Steffen, and J. E. Box, 2001: Mesoscale modeling of katabatic winds over Greenland with the Polar MM5. Mon. Wea. Rev., 129, 2290-2309.

——, A. J. Monaghan, J. G. Powers, J. J. Cassano, H.-L. Wei, Y.-H. Kuo, and A. Pellegrini, 2003: Antarctic Mesoscale Prediction System (AMPS): A case study from the 2000-01 field season. Mon. Wea. Rev., 131, 412-434.

_, L. Bai, and G. G. Bjarnason, 2005a: High-resolution regional climate simulations over Iceland using Polar MM5. Mon. Wea. Rev., 133, 3527-3547.

—_, E. R. Toracinta, R. J. Oglesby, J. L. Fastook, and T. J. Hughes, 2005b: LGM summer climate on the southern margin of the Laurentide Ice Sheet: Wet or dry? J. Climate, 18, 3317-3338.

_, R. L. Fogt, K. E. Hodges, and J. E. Walsh, 2007: A tropospheric assessment of the ERA-40, NCEP, and JRA-25 global reanalyses in the polar regions. J. Geophys. Res., 112, D10111, doi:10.1029/2006JD007859.

— K. M. Hines, and L.-S. Bai, 2009: Developments and testing of Polar Weather Research and Forecasting model: 2. Arctic Ocean. J. Geophys. Res., 114, D08122, doi:10.1029/ 2008JD010300.

_ , Y.-H. Kuo, M. C. Serreze, J. E. Walsh, L. S. Bai, M. Barlage, K. M. Hines, and A. S. Slater, 2010: Arctic system reanalysis: Call for community involvement. Eos, Trans. Amer. Geophys. Union, 91, doi:10.1029/2010EO020001.

Cavalieri, D., M. Thorsten, and J. Comiso, 2004: AMSR-E/Aqua Daily L3 $25 \mathrm{~km}$ brightness temperature and sea ice concentration polar grids V002. National Snow and Ice Data Center, Boulder, CO, digital media. [Available online at http://nsidc. org/data/docs/daac/ae_si25_25km_tb_and_sea_ice.gd.html.]

Chapin, F. S., III, and Coauthors, 2000: Arctic and boreal ecosystems of western North America as components of the climate system. Global Change Biol., 6, 211-223.

- , and Coauthors, 2005: Role of land-surface changes in Arctic summer warming. Science, 310, 657-660.

Chen, F., and Coauthors, 2007: Description and evaluation of the characteristics of the NCAR High-Resolution Land Data Assimilation system. J. Appl. Meteor. Climatol., 46, 694-713.

Dong, X., and G. G. Mace, 2003: Arctic stratus cloud properties and radiative forcing derived from ground-based data collected at Barrow, Alaska. J. Climate, 16, 445-461.

Doran, J. C., S. Zhong, J. C. Liljegren, and C. Jakob, 2002: A comparison of cloud properties at a coastal and inland site at the North Slope of Alaska. J. Geophys. Res., 107, 4120, doi:10.1029/2001JD000819.

—, J. C. Barnard, and W. J. Shaw, 2006: Modification of summertime Arctic cloud characteristics between a coastal and inland site. J. Climate, 19, 3207-3219.

Ek, M. B., K. E. Mitchell, Y. Lin, E. Rogers, P. Grunmann, V. Koren, G. Gayno, and J. D. Tarpley, 2003: Implementation 
of Noah land surface model advances in the National Centers for Environmental Prediction operational mesoscale Eta model. J. Geophys. Res., 108, 8851, doi:10.1029/2002JD003296.

Ellingson, R. G., K. Stamnes, J. A. Curry, J. E. Walsh, and B. D. Zak, 1999: Overview of North Slope of Alaska/adjacent Arctic Ocean science issues. J. Climate, 12, 46-63.

Essery, R., and P. Etchevers, 2004: Parameter sensitivity in simulations of snowmelt. J. Geophys. Res., 109, D20111, doi:10.1029/2004JD005036.

Euskirchen, E. S., A. D. McGuire, F. S. Chapin III, S. Yi, and C. C. Thompson, 2009: Changes in vegetation in northern Alaska under scenarios of climate change, 2003-2100: Implications for climate feedbacks. Ecol. Appl., 19, 1022-1043.

Fogt, R. L., and D. H. Bromwich, 2008: Atmospheric moisture and cloud cover characteristics forecast by AMPS. Wea. Forecasting, 23, 914-930.

Giorgi, F., M. R. Marinucci, and G. T. Bates, 1993: Development of a second-generation regional climate model (RegCM2) Part I: Boundary-layer and radiative transfer processes. Mon Wea. Rev., 121, 2794-2813.

Global Climate and Weather Modeling Branch, 2003: The GFS atmospheric model. NCEP Office Note 442, 14 pp. [Available online at http://www.emc.ncep.noaa.gov/officenotes/newernotes/ on442.pdf.]

Grell, G. A., and D. Dévényi, 2002: A generalized approach to parameterizing convection combining ensemble and data assimilation techniques. Geophys. Res. Lett., 29, 1693 , doi:10.1029/2002GL015311.

Guo, Z., D. H. Bromwich, and J. J. Cassano, 2003: Evaluation of Polar MM5 simulations of Antarctic atmospheric circulation. Mon. Wea. Rev., 131, 384-411.

Harazono, Y., M. Yoshimoto, M. Mano, G. L. Vourlitis, and W. C. Oechel, 1998: Characteristics of energy and water budgets over wet sedge and tussock tundra ecosystems at North Slope in Alaska. Hydrol. Processes, 12, 2163-2183.

Hines, K. M., and D. H. Bromwich, 2008: Development and testing of Polar WRF. Part I: Greenland Ice Sheet meteorology. Mon. Wea. Rev., 136, 1971-1989.

Hollingsworth, J., 2005: Bonanza Creek Experimental Forest: Hourly temperature (sample, min, $\max$ ) at $50 \mathrm{~cm}$ and $150 \mathrm{~cm}$ from 1988 to present. Bonanza Creek LTER - University of Alaska Fairbanks. BNZ:1. [Available online at http://www. lter.uaf.edu/data_detail.cfm?datafile_pkey $=1$.]

Janjić, Z. I., 2002: Nonsingular implementation of the MellorYamada level 2.5 scheme in the NCEP Meso model. NCEP Office Note 437, 61 pp.

Jones, B. M., C. A. Kolden, R. Jandt, J. T. Abatzoglou, F. Urban, and C. D. Arp, 2009: Fire behavior, weather, and burn severity of the 2007 Anaktuvuk River tundra fire, North Slope, Alaska. Arct. Antarct. Alp. Res., 41, 309-316, doi:10.1657/ 1938-4246-41.3.309.

Juday, G. P., and Coauthors, 2005: Forests, land management, and agriculture. Arctic Climate Impact Assessment, C. Symon, L. Arris, and B. Heal, Eds., Cambridge University Press, 781-862.

Kane, D. L., and W. S. Reeburgh, 1998: Introduction to the special section: Land-Air-Ice Interactions (LAII) Flux Study. J. Geophys. Res., 103, 28 913-28 915.

_ J. P. McNamara, D. Yang, P. Q. Olsson, and R. E. Gieck, 2003: An extreme rainfall/runoff event in arctic Alaska. J. Hydrometeor., 4, 1220-1228.

Kay, J. E., T. L'Ecuyer, A. Gettelman, G. Stephens, and C. O'Dell, 2008: The contribution of cloud and radiation anomalies to the
2007 Arctic sea ice extent minimum. Geophys. Res. Lett., 35, L08503, doi:10.1029/2008GL033451.

Lawrence, D. M., and A. G. Slater, 2005: A projection of severe near-surface permafrost degradadation during the 21st century. J. Geophys. Res. Lett., 32, L24401, doi:10.1029/ 2005GL025080.

- and - 2008: Incorporating organic soil into a global climate model. Climate Dyn., 30, 145-160, doi:10.1007/s00382007-0278-1.

, - , R. A. Tomas, M. M. Holland, and C. Deser, 2008: Accelerated Arctic land warming and permafrost degradation during rapid sea ice loss. Geophys. Res. Lett., 35, L11506, doi:10.1029/2008GL033985.

Lee, M. S., 2005: Preliminary tests of First Guess at Appropriate Time (FGAT) with WRF 3DVAR and WRF model. J. Korean Meteor. Soc., 41, 495-505.

Ling, F., and T. Zhang, 2004: A numerical model for surface energy balance and thermal regime of the active layer and permafrost containing unfrozen water. Cold Reg. Sci. Technol., 38, 1-15.

$\ldots$, and _ 2006: Sensitivity of ground thermal regime and surface energy fluxes to tundra snow density in northern Alaska. Cold Reg. Sci. Technol., 44, 121-130.

Livneh, B., Y. Xia, K. E. Mitchell, M. B. Ek, and D. P. Lettenmaier, 2010: Noah LSM snow model diagnostics and enhancements. J. Hydrometeor., 11, 721-738.

Lloyd, A., and A. Bunn, 2007: Response of the circumpolar boreal forest to 20 th century climate variability. Environ. Res. Lett., 2, 045013, doi:10.1088/1748-9326/2/4/045013.

Lynch, A. H., W. L. Chapman, J. E. Walsh, and G. Weller, 1995: Development of a regional climate model of the western Arctic. J. Climate, 8, 1555-1570.

, D. L. McGinnis, and D. A. Bailey, 1998: Snow-albedo feedback and the spring transition in a regional climate system model: Influence of land surface model. J. Geophys. Res., 103, 29 037-29 049.

, G. B. Bonan, F. S. Chapin III, and W. Wu, 1999a: Impact of tundra ecosystems on the surface energy budget and climate of Alaska. J. Geophys. Res., 104, 6647-6660.

—, F. S. Chapin III, L. D. Hinzman, W. Wu, E. Lilly, G. Vourlitis, and E. Kim, 1999b: Surface energy balance on the Arctic tundra: Measurements and models. J. Climate, 12, 2585-2606.

— A. G. Slater, and M. Serreze, 2001: The Alaskan Arctic frontal zone: Forcing by orography, coastal contrast, and the boreal forest. J. Climate, 14, 4351-4362.

Marshall, S., and R. J. Oglesby, 1994: An improved snow hydrology for GCMs. Part 1: Snow cover fraction, albedo, grain size, and age. Climate Dyn., 10, 21-37.

McFarlane, S. A., Y. Shi, and C. N. Long, 2009: A year of radiation measurements at the North Slope of Alaska. ARM and Climate Change Prediction Program Metric Rep. DOE/SCARM/P-09-010, 7 pp. [Available online at http://www.arm. gov/publications/programdocs/doe-sc-arm-p-09-010.pdf.]

McGuire, A. D., M. Sturm, and F. S. Chapin III, 2003: Arctic Transitions in the Land-Atmosphere System (ATLAS): Background, objectives, results, and future directions. J. Geophys. Res., 108, 8166, doi:10.1029/2002JD002367.

Mölders, N., and G. Kramm, 2010: A case study on wintertime inversions in interior Alaska with WRF. Atmos. Res., 95, 314-332.

, H. Luijting, and K. Sassen, 2008: Use of Atmospheric Radiation Measurement program data from Barrow, Alaska, for evaluation and development of snow-albedo parameterizations. Meteor. Atmos. Phys., 99, 199-219. 
Morrison, H., J. A. Curry, and V. I. Khvorostyanov, 2005: A new double-moment microphysics parameterization for application in cloud and climate models. Part I: Description. J. Atmos. Sci., 62, 1665-1677.

Onogi, K., and Coauthors, 2007: The JRA-25 Reanalysis. J. Meteor. Soc. Japan, 85, 369-432.

Perovich, D. K., S. V. Nghiem, T. Markus, and A. Schweiger, 2007: Seasonal evolution and interannual variability of the local solar energy absorbed by the Arctic sea ice-ocean system. J. Geophys. Res., 112, C03005, doi:10.1029/2006JC003558.

Powers, J. G., A. J. Monaghan, A. M. Cayette, D. H. Bromwich, Y.-H. Kuo, and K. W. Manning, 2003: Real-time mesoscale modeling over Antarctica: The Antarctic Mesoscale Prediction System (AMPS). Bull. Amer. Meteor. Soc., 84, 15331545.

Rinke, A., and Coauthors, 2006: Evaluation of an ensemble of Arctic regional climate models: Spatiotemporal fields during the SHEBA year. Climate Dyn., 26, 459-472, doi:10.1007/ s00382-005-0095-3.

Roberts, A., and Coauthors, 2009: Science plan for Arctic system modeling. National Science Foundation Office of Polar Programs Rep., 53 pp. [Available online at http://research.iarc. uaf.edu/presentations/ASM_08/ASM_Science_Plan_draft_ 02Dec08.doc.]

Schweiger, A. J., J. Zhang, R. W. Lindsay, and M. Steele, 2008: Did unusually sunny skies help drive the record sea ice minimum of 2007? Geophys. Res. Lett., 35, L10503, doi:10.1029/ 2008 GL033463.

Serreze, M. C., D. H. Bromwich, M. P. Clark, A. J. Etringer, T. Zhang, and R. Lammers, 2002: Large-scale hydro-climatology of the terrestrial Arctic drainage system. J. Geophys. Res., 108, 8160, doi:10.1029/2001JD000919.

Shulski, M., and G. Wendler, 2007: The Climate of Alaska. University of Alaska Press, $216 \mathrm{pp}$.

Skamarock, W. C., J. B. Klemp, J. Dudhia, D. O. Gill, D. M. Barker, W. Wang, and J. G. Powers, 2005: A description of the Advanced Research WRF Version 2. NCAR Tech. Note NCAR/TN468+STR, 88 pp. [Available from UCAR Communications, P.O. Box 3000, Boulder, CO 80307.]

, and Coauthors, 2008: A description of the Advanced Research WRF Version 3. NCAR Tech. Note NCAR/TN475+STR, 125 pp. [Available online at http://www.mmm.ucar. edu/wrf/users/docs/arw_v3.pdf.]

Slater, A. G., T. J. Bohn, J. L. McCreight, M. C. Serreze, and D. P. Lettenmeier, 2007: A multimodel simulation of pan-Arctic hydrology. J. Geophys. Res., 112, G04S45, doi:10.1029/ 2006JG000303.

Spreen, G., L. Kaleschke, and G. Heygster, 2008: Sea ice remote sensing using AMSR-E 89-GHz channels. J. Geophys. Res., 113, C02S03, doi:10.1029/2005JC003384.

Stafford, J. M., G. Wendler, and J. Curtis, 2000: Temperature and precipitation of Alaska 50 year trend analysis. Theor. Appl. Climatol., 67, 33-44.

Stone, R. S., E. G. Dutton, J. M. Harris, and D. Longenecker, 2002: Earlier spring snowmelt in northern Alaska as an indicator of climate change. J. Geophys. Res., 107, 4089, doi:10.1029/ 2000JD000286.

Stroeve, J., M. M. Holland, W. Meier, T. Scambos, and M. Serreze, 2007: Arctic sea ice decline: Faster than forecast. Geophys. Res. Lett., 34, L09501, doi:10.1029/2007GL029703.

_ M. Serreze, S. Drobot, S. Gearheard, M. Holland, J. Maslanik, W. Meier, and T. Scambos, 2008: Arctic sea ice extent plummets in 2007. Eos, Trans. Amer. Geophys. Union, 89, doi:10.1029/2008EO020001.

Tjernström, M., and Coauthors, 2005: Modelling the Arctic boundary layer: An evaluation of six ARCMIP regional-scale models with data from the SHEBA project. Bound.-Layer Meteor., 117, 337-381.

Uttal, T., and Coauthors, 2002: Surface heat budget of the Arctic Ocean. Bull. Amer. Meteor. Soc., 83, 255-275.

Walsh, J. E., W. L. Chapman, V. Romanovsky, J. H. Christensen, and M. Stendel, 2008: Global climate model performance over Alaska and Greenland. J. Climate, 21, 6156-6174.

,-- , and D. Portis, 2009: Arctic cloud fraction and radiative fluxes in atmospheric reanalyses. J. Climate, 22, 2316-2334.

Warren, S. G., 1982: Optical properties of snow. Rev. Geophys. Space Phys., 20, 67-89.

Wendler, G., and F. Eaton, 1990: Surface radiation budget at Barrow, Alaska. Theor. Appl. Climatol., 41, 107-115.

Wilson, A. B., 2010: Enhancement of Polar WRF atmospheric and surface processes: An annual simulation. M.S. thesis, Dept. of Geography, The Ohio State University, $171 \mathrm{pp}$. [Available online at http://etd.ohiolink.edu/view.cgi?acc_num $=$ osu1268066611.]

Zhang, T., R. G. Barry, K. Knowles, J. A. Heginbottom, and J. Brown, 2008: Statistics and characteristics of permafrost and ground-ice distribution in the Northern Hemisphere. Polar Geogr., 31, 47-68.

Zimov, S. A., E. A. Schuur, and F. S. Chapin III, 2006: Permafrost and the global carbon budget. Science, 312, 1612-1613. 